\title{
Benthic sulfate reduction along the Chesapeake Bay central channel. I. Spatial trends and controls
}

\author{
M. C. Marvin-DiPasquale*, D. G. Capone \\ University of Maryland Center for Environmental Science, Chesapeake Biological Laboratory, \\ PO Box 38, Solomons, Maryland 20688, USA
}

\begin{abstract}
Factors controlling the spatial distribution of benthic sulfate reduction (SR) were investigated at 3 stations [upper (UB), mid (MB) and lower bay (L.B)] along the Chesapeake Bay (eastern USA) central channel from early spring through late fall, 1989 to 1994 . Annual rates of 0 to $12 \mathrm{~cm}$ depthintegrated $\mathrm{SR}$ were $0.96,9.62$ and $6.33 \mathrm{~mol} \mathrm{~S} \mathrm{~m}^{-2} \mathrm{r}^{-1}$ for $\mathrm{UB}, \mathrm{MB}$ and $\mathrm{LB}$, respectively, as calculated from ${ }^{35} \mathrm{SO}_{4}{ }^{2-}$ incubations. SR was carbon limited at UB, LB, and at the sediment surface at $M B$, and $\mathrm{SO}_{4}{ }^{2-}$ limited at depth at $\mathrm{MB}$. Temperature explained 33 to $68 \%$ of the variability in annual rates, with an apparent influence on SR which increased in the seaward direction in surface sediments. We speculate that the enhanced response of SR to temperature in LB surface sediments was linked to seasonal variations in macrofaunal actıvity associated with temperature. Estimates of reduced-S burial indicated that only 4 to $8 \%$ of sulfur reduced annually was buried. as Fe-S minerals at MB and LB, with the remainder presumably being reoxidized. In contrast, $>50 \%$ of the sulfur reduced annually was buried at UB, due to comparatively low SR rates and the high concentration of reactive iron in the oligonaiine region. SR mineralized 18 to $32 \%$ of the annual primary production. Our results indicate that organic quality may be more important than the absolute quantity of organic loading in dictating the magnitude of benthic SR rates along an estuarine gradient. Spatial trends in SR reflected the combined influence of deposited organic matter quality and quantity, $\mathrm{SO}_{4}{ }^{2-}$ availability, the presence or absence of benthic macrofauna, overlying water dissolved $\mathrm{O}_{2}$ conditions, reduced-S reoxidation dynamics, and iron-sulfide mineral formation.
\end{abstract}

KEY WORDS: Sulfate reduction · Anaerobic metabolism - Sediment Estuary · Chesapeake Bay

\section{INTRODUCTION}

Estuarine and shallow coastal environments characteristically exhibit a large net flux of organic matter deposited to the benthos (Wollast 1983). Dissolved $\mathrm{O}_{2}$ is rapidly depleted and aerobic respiration is limited to a narrow zone $(<5 \mathrm{~mm})$ at the surface of non-bioturbated sediments (Revsbech et al. 1980, Andersen \& Helder 1987). Consequently, anaerobic respiration plays an important role in organic mineralization, nutrient regeneration, and benthic-pelagic coupling in

\footnotetext{
- Present address: U.S. Geological Survey, Water Resources Division, MS 480, 345 Middlefield Rd, Menlo Park, California94025, USA.E-mail:mmarvin@usgs.gov
}

these systems (Jørgensen 1977, Sørensen et al. 1979. Canfield 1989). Due to the relative scarcity of suitable electron acceptors for Fe reduction, Mn reduction, and denitrification, sulfate reduction (SR) and methanogenesis are the primary pathways of marine benthic anaerobic respiration (Capone \& Kiene 1988), with the former out-competing the latter for mutually used organic substrates and $\mathrm{H}_{2}$ (Oremland \& Polcin 1982).

The extent of $\mathrm{C}$ flow through $\mathrm{SR}$ varies spatially in natural systems, both regionally and with sediment depth. Environmental factors which can account for this variability include: temperature (Westrich \& Berner 1988), organic quality (Westrich \& Berner 1984), electron donor and acceptor availability (Nedwell \& Abram 1979, Boudreau \& Westrich 1984), sedimentation rate (Berner 1978), redox conditions (Skyring 
1987) and bioturbation (Hines et al. 1982, Bussmann \& Reichardt 1991). While individually these controls have been considered in detail, a more integrated view of their combined effect and potential interaction is needed in order to explain the spatial and temporal trends of anaerobic metabolism observed in natural systems. As part of the 6 yr (1989 to 1994) Land Margin Ecosystem Research (LMER) program, we repeatedly measured SR and auxiliary parameters at 3 benthic sites, representing 3 distinct salinity regimes (oligohaline, mesohaline, and polyhaline), along the central channel of the Chesapeake Bay (eastern USA).

Here we describe the spatial trends in benthic SR along the estuarine gradient and with sediment depth, and explore the factors which control SR rates in these 2 dimensions. We also assess which factors control the spatial differences in (1) the apparent temperature influence on $S R,(2)$ reduced-S burial and reoxidation and (3) annual primary production consumed via SR.

\section{METHODS AND APPROACH}

Sampling. The 3 benthic sites (upper, mid and lower bay $\mathrm{UB}, \mathrm{MB}$, and $\mathrm{LB}$ ) were all located on the western slope of the Chesapeake Bay central channel (Fig. 1). The coordinates for these stations were: UB, $39^{\circ} 20.9^{\prime} \mathrm{N}, 76^{\circ} 10.9^{\prime} \mathrm{W} ; \mathrm{MB}, 38^{\circ} 341^{\prime} \mathrm{N}, 76^{\circ} 26.6^{\prime} \mathrm{W}$, and $L B, 37^{\circ} 16.1^{\prime} \mathrm{N}, 76^{\circ} 09.0^{\prime} \mathrm{W}$ Average water column depths were 10,15 , and $12 \mathrm{~m}$, respectively, During the first study year (1989), sampling was conducted monthly, from March to November (excluding October), in order to discern overall seasonal trends. Subsequently, 3 to 5 annual cruises were timed to include spring, summer and fall periods at least once per year at each site.

Sediment and pore water processing. Sediment box cores $(9 \times 16 \times 34 \mathrm{~cm})$ were collected and stored in coolers filled with ambient bottom water until further shipboard processing The top 16 to $20 \mathrm{~cm}$ of one core was sampled at 0.5 to $2 \mathrm{~cm}$ intervals for porosity, total organic matter (TOM), and pore water $\mathrm{SO}_{4}{ }^{2-}, \mathrm{Cl}^{-}$, and free sulfide $\left(\mathrm{\Sigma H}_{2} \mathrm{~S}\right)$ (MB only). Two subsamples were taken from either side of the vertical center of each depth interval. using a plastic syringe ( 1 or $3 \mathrm{~cm}^{3}$ ) with the needle end cut off, and transferred into pre-weighed serum vials, crimp sealed, and stored frozen until subsequent analysis of porosity and TOM. Two $50 \mathrm{ml}$ plastic centrifuge tubes were filled with the remaining sediment while continualiy flushing with $\mathrm{N}_{2}$ gas (MB only) to minimize reduced sulfur oxidation. After centrifugation, pore water supernatant (5 to $15 \mathrm{ml}$ ) was filtered through pre-combusted Whatman GF/F filters into pre-combusted glass scintillation vials. For MB samples, pre-weighed vials contained $0.5 \mathrm{ml}$ of $10 \%(\mathrm{w} / \mathrm{v})$ zinc acetate to precipitate any free sulfide as $\mathrm{ZnS}$. Pore water samples were stored frozen until later analysis of $\mathrm{SO}_{4}{ }^{2-}, \mathrm{Cl}^{-}$, and $\mathrm{\Sigma H}_{2} \mathrm{~S}$.

Porosity was calculated from the difference in the wet and dry sediment weights, after drying samples overnight at $80^{\circ} \mathrm{C}$, and assuming constant pore water and dry sediment densities of 1.0 and $2.6 \mathrm{~g} \mathrm{ml}^{-1}$, respectively. Samples were then combusted at $475^{\circ} \mathrm{C}$ for a minimum of $6 \mathrm{~h}$, and TOM was calculated as the \% loss dry weight. The previously 'fixed' $M B$ pore water samples were homogenized and the $\mathrm{ZnS}$ pre-

Fig. 1. Chesapeake Bay, USA, indicating the LMER benthic sites 
cipitate was subsampled and assayed for $\mathrm{LH}_{2} \mathrm{~S}$ (Cline 1969). The remaining pore water was filtered (Whatman $\mathrm{GF} / \mathrm{F}$ ), and pore water $\mathrm{SO}_{4}{ }^{2-}$ and $\mathrm{Cl}^{-}$were measured on a Dionex (Model 2020i) ion chromatograph with conductivity detection.

Additional surface sediment (top $1 \mathrm{~cm}$ ) was collected and stored frozen. Particulate carbon (PC) and particulate nitrogen (PN) were analyzed via thermal conductivity detection with a Perkin-Elmer 240-XA Elemental Analyzer. Chlorophyll a (chl a) was analyzed fluorometrically (Strickland \& Parsons 1972). Sediment redox (Eh) profiles (0 to $10 \mathrm{~cm}$ ) were measured as described by Cowen \& Boynton (1996). Bottom water dissolved $\mathrm{O}_{2}$, temperature and salinity were measured using a Seabird conductivity, temperature and depth sensor (CTD), or a Hydrolab 4000 temperature, $\mathrm{O}_{2}$, and salinity probe.

Sulfate reduction rates and reduced sulfur pools. Duplicate subcores were taken with polycarbonate coring tubes $(2.5 \mathrm{~cm}$ i.d. $\times 20 \mathrm{~cm})$ from a separate single box core. The depth of bottom water overlying the sediment surface was adjusted to $1-3 \mathrm{~cm}$. Subcores were sealed full with bottom water and stoppered at the top when dissolved $\mathrm{O}_{2}$ conditions were hypoxic or anoxic, and left open at the top when bottom water was $\mathrm{O}_{2}$ replete, to approximately maintain the original bottom water dissolved $\mathrm{O}_{2}$ conditions during incubation. Depth-specific SR rate constants were measured throughout the top $12 \mathrm{~cm}$ of sediment at $2 \mathrm{~cm}$ intervais using a whole core ${ }^{35} \mathrm{SO}_{4}{ }^{2-}$ radiotracer method (Jorgensen 1978) as modified by Roden \& Tuttle (1993a). Following radiotracer injection, cores were incubated onboard for $4 \mathrm{~h}$ in a cooler with bottom water at in situ temperatures. Incubations were initiated within $2 \mathrm{~h}$ of sediment collection and terminated by injecting $0.5 \mathrm{ml}$ of $10 \% \mathrm{Zn}$ acetate into the original points of radiotracer addition. Subcores were stored frozen until further processing, which was generally completed within 1 mo.

Frozen sediment cores were sectioned into $2 \mathrm{~cm}$ intervals. Total (inorganic) reduced ${ }^{35} \mathrm{~S}$ (TRS) in each segment was liberated during a $1 \mathrm{~h}$ acidic reducedchromium distillation, using $\mathrm{O}_{2}$-free $\mathrm{N}_{2}$ as the flushing gas. $\mathrm{H}_{2} \mathrm{~S}$ gas was trapped as $\mathrm{ZnS}$, by bubbling through a 10\% $\mathrm{Zn}$ acetate solution (Zhabina \& Volkov 1978). Typically, cores were assayed for TRS only. On 6 sampling dates (March, April, May and August 1989, and April and July 1994) both inorganic acid volatile sulfur (AVS) and non-acid volatile sulfur (NAVS) fractions were analyzed independently (Roden \& Tuttle 1993a). Duplicate aliquots of $\mathrm{ZnS}$ from each fraction were assayed for radioactivity via liquid scintillation counting. Sample quench was corrected using external quench standards. Zero order $\mathrm{SO}_{4}{ }^{2-}$ turnover rate constants ( $k$ ) for each $2 \mathrm{~cm}$ depth interval were calculated as:

$$
k_{x}=N_{\mathrm{R}} \times N_{0}^{-1} \times t^{-1}
$$

where $k_{\mathrm{x}}$ is the turnover rate constant at depth $x\left(\mathrm{~d}^{-1}\right)$, $N_{\mathrm{R}}$ is the activity of trapped $\mathrm{Zn}^{35} \mathrm{~S}$ at depth $\mathrm{x}(\mathrm{dpm})$, corrected for radioisotope decay during storage, $N_{0}$ is the original injection ${ }^{35} \mathrm{SO}_{4}{ }^{2-}$ activity (dpm), and $t$ is the incubation time (d). SR rates for each $2 \mathrm{~cm}$ depth interval were calculated as:

$$
\mathrm{SR}_{x}=k_{x} \times\left[\mathrm{SO}_{4}^{2-}\right]_{x} \times \phi_{x} \times 20
$$

where $\mathrm{SR}_{x}$ is the sulfate reduction rate at depth $x$ ( $\left.\mathrm{mmol} \mathrm{m}{ }^{-2} \mathrm{~d}^{-1}\right),\left[\mathrm{SO}_{4}{ }^{2-}\right]_{x}$ is the pore water $\mathrm{SO}_{4}{ }^{2-}$ concentration at depth $x\left(\mathrm{mmol} \mathrm{l}^{-1}\right), \phi_{x}$ is the porosity at depth $x$, and the constant 20 converts from volume to area for a $2 \mathrm{~cm}$ deep interval. The 0 to $12 \mathrm{~cm}$ depthintegrated $\mathrm{SR}$ rate $\left(\mathrm{SR}_{12}\right)$ was calculated as the sum of the six $2 \mathrm{~cm}$ intervals. The concentration of in situ TRS (or AVS and NAVS individually) was also measured in duplicate for each depth interval by taking a second set of aliquots of the ZnS precipitate and assaying colorometrically (Cline 1969). The incorporation of reduced ${ }^{35} \mathrm{~S}$ into organic fractions was not assessed.

Annual-integrated SR rates and temperature model. Site-specific annual (March to November) integrated $\mathrm{SR}$ rates were calculated by summing the average monthly SR rates for this period (Method A) or by using an Arrhenius type temperature model (Method B) (Roden \& Tuttle 1993a). In the second case, a temperature model function was fit to bottom water temperature data, such that:

$T(t)=T_{1}+0.5 \times\left(T_{2}-T_{1}\right) \times[1-\cos (2 \pi t / 365-2 \pi Q / 365)]$

where $t$ is time (Julian day), $T_{1}$ and $T_{2}$ are the annual minimum and maximum temperatures $\left({ }^{\circ} \mathrm{C}\right)$, respectively, and $Q$ is the Julian date of minimum temperature (Rice 1986). The shallower UB site was often 3 to $5^{\circ} \mathrm{C}$ warmer than the deeper $M B$ and $L B$ sites, while the difference between $M B$ and $L B$ was generally less than 1 to $2^{\circ} \mathrm{C}$ on any given sampling cruise. Consequently, the temperature model was fit to the combined data from MB and LB, and to UB data separately.

A regression, with the same form as the linear Arrhenius equation, was fit to the SR and temperature data:

$$
\ln [r(t)]=\left(-C_{1} / R\right) \times T^{-1}+\ln (A)
$$

where $r(t)$ is the areal SR rate $\left(\mathrm{mmol} \mathrm{SO}{ }_{4}{ }^{2-} \mathrm{m}^{-2} \mathrm{~d}^{-1}\right), T$ is temperature $(K), A$ is a pre-exponential factor, $C_{t}$ is the temperature characteristic $\left(\mathrm{kJ} \mathrm{mol}^{-1}\right)$, and $R$ is the gas constant $\left(0.008314 \mathrm{~kJ} \mathrm{~mol}^{-1} \mathrm{~K}^{-1}\right) . C_{t}$ and $A$ values were calculated from the regression slope and $y$-intercept, respectively. Daily SR rates were calculated for Julian days 61 to 334 (March 1 to November 31) using $C_{t}$ and $A$ values calculated from Eq. (4) and daily temperatures predicted from Eq. (3). Annual SR rates were 
calculated from the integration of these modelpredicted daily rates over the defined time period.

The parameter $C_{t}$ is not the same as the activation energy $\left(E_{\alpha}\right)$ derived from kinetic theory and calculated from the true Arrhenius equation, which describes the energy input required for a chemical reaction to proceed (Brady \& Humiston 1982). Nor is it the same as the $E_{a}$ adapted to microbial enzyme kinetics studies, whereby reaction rates of the same microbial population are measured for a range of incubation temperatures (Abdollahi \& Nedwell 1979, Westrich \& Berner 1988, Swider \& Mackin 1989). The $C_{t}$ described here, while calculated in the same fashion and having the same units as $E_{a}$, differs in that the SR rate and bottom water temperature data used in Eq. (4) were collected over many sampling periods, and therefore it does not represent a measure of cellular enzyme kinetics explicitly. $C$, reflects the response of SR not only to temperature, but also to factors that covary with temperature, such as changing microbial populations, sediment redox conditions, organic loading, the influence of alternative electron acceptors, and bioturbation. Thus, $C_{t}$ implicitly inchües the complex and often unquantifiable suite of temperature-dependent biotic and abiotic reactions that mediate SR. Recognizing this important distinction, we use this approach as an integrated measure of the direct and indirect temperature influence on SR, and to compare our results with previous investigations that have assessed time-integrated $\mathrm{SR}$ in a similar manner (Jørgensen 1977. Crill \& Martens 1987, King 1988, Westrich \& Berner 1988, Roden \& Tuttle 1993a).

\section{RESULTS}

\section{Biogeochemical site characterization}

The 3 benthic sites (UB, MB, and LB; Fig. 1) differed in salinity regime, sediment type, biogeochemical pool size, infauna, and in the quality and quantity of organic carbon deposition to the benthos. Fig. 2 summarizes mean values of relevant site-specific biogeochemical data.

Site UB was characterized by low-salinity (Fig. 2a), oxygenated bottom water overlying silty-clay sediment (Hill \& Halka 1988) which was well oxidized (positive Eh values; Fig. $2 \mathrm{c}$ ) with a 1 to $3 \mathrm{~cm}$ brown surface layer overlying a gray/black deeper layer. A diverse benthic community of bivalves and polychaetes was regularly observed at this site. Autochthonous primary production in this region of the Bay is light limited due to sediment resuspension and high concentrations of water column suspended solids transported by the Susquehanna River (Biggs \& Flemer 1972, Harding et al.
1986). This was reflected in the substantially lower surficial sediment chl a concentration at UB as compared with $\mathrm{MB}$ and LB (Fig. 2g). Site-specific PC/PN ratios (Fig. 2f) indicated that UB benthic deposition has a substantial terrestrial component relative to the 2 down-bay sites (Biggs \& Flemer 1972, Hennessee et al. 1986). PC/PN ratios are often used as an indicator of organic matter lability, with increasing ratios associated with decreasing lability due to the larger fraction of structural C based components (Hedges et al. 1986, Hedges et al. 1988, Peterson et al. 1993). That a substantial fraction of terrestrial organic matter was deposited to the UB benthos was further confirmed by the low $\delta^{13} \mathrm{C}$ value $(<-25 \%$; Fig. $2 \mathrm{k}$ ) at UB, compared to $\mathrm{MB}$ and $\mathrm{LB}$, as land plants typically have a lower $\delta^{13} \mathrm{C}$ signal than do phytoplankton (Quay et al. 1992). This trend, of decreasing $\delta^{13} \mathrm{C}$ values and increasing $C: N$ ratios, going from marine to terrestial end-members, is a common feature of estuaries (Cifuentes et al. 1988, Matson \& Brinson 1990).

Site MB sediment was gray/black in appearance and strongly reducing (Fig. $2 \mathrm{c}$ ), with a thin $(<1 \mathrm{~cm})$ brown surface lâyer apparent only in eâriy spring or lâte autumn. MB sediments were also comprised of siltyclay (Hill \& Halka 1988) with high concentrations of TOM (Fig. 2j), PC (Fig. 2d), PN (Fig. 2e), and chl a (Fig. 2g). These variables, along with the low PC/PN ratio (Fig. 2f) and comparatively high $\delta^{13} \mathrm{C}$ value (Fig. $2 \mathrm{k}$ ), confirm that the primary source of organic matter to the mesohaline benthos is phytoplankton detritus (Schubel \& Biggs 1968, Biggs \& Flemer 1972). Seasonally hypoxic/anoxic bottom water conditions were frequently observed at $M B$, particularly during July and August (Boynton et al. 1991, Cowen \& Boynton 1996). While some bivalve spat settled at MB during early spring, all forms of viable macrofauna were absent by early summer due to the strong reducing conditions and lack of $\mathrm{O}_{2}$ (Holland et al. 1977, Holland 1985). Thus, no appreciable bioturbation is thought to have occurred at $\mathrm{MB}$ during the majority of the sampling period

Site LB sediment was composed of low porosity (Fig 2b) silty-sand (Hobbs 1983). The low PC/PN (Fig. 2f) and high $\delta^{13} \mathrm{C}$ (Fig. $2 \mathrm{k}$ ) values indicate that, like $\mathrm{MB}$, phytoplankton is the primary source of organic matter deposited to this site. Allochthonous total organic carbon comprises only 3 to $4 \%$ of total organic carbon inputs to both MB and LB (Kemp et al. 1997). However, the lower TOM (Fig 2j), PC (Fig. 2d), PN (Fig. 2e), and chl a (Fig. $2 g$ ) values at LB compared to $\mathrm{MB}$ suggest that (1) less particulate organic matter (POM) is deposited to the benthos, (2) the conversion of POM to dissolved organic matter (DOM) and subsequent mineralization is more rapid at LB, and/or (3) macrofaunal mixing dilutes the fresh POM pool in 

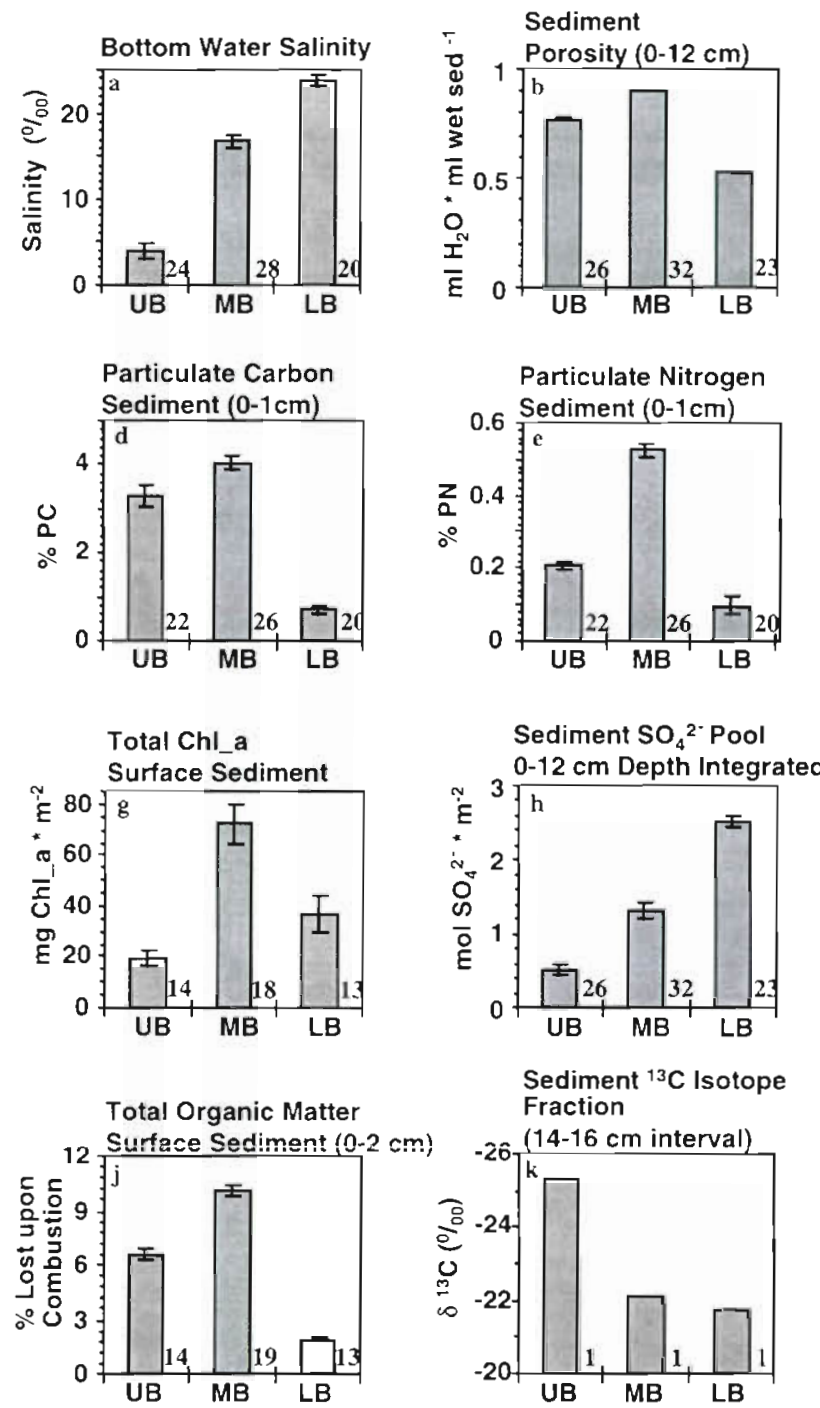
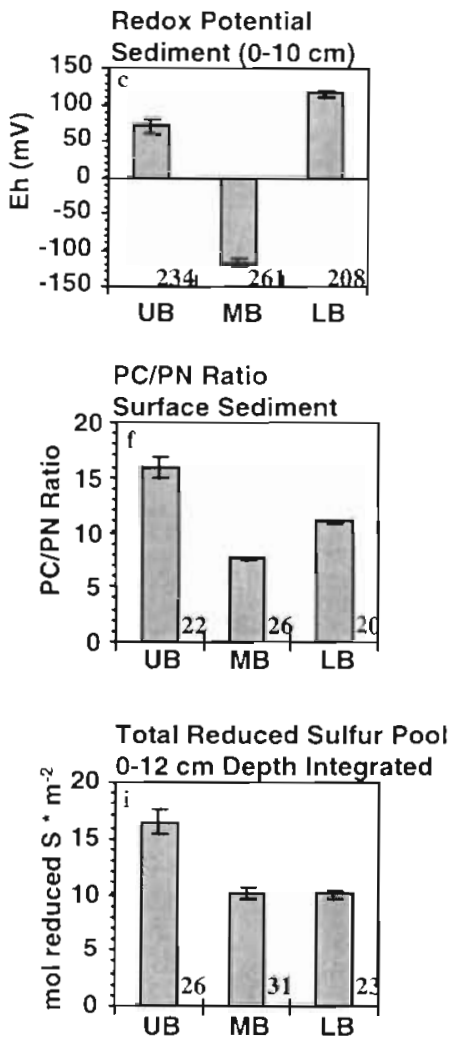

Fig. 2. Site and sediment bulk averages of relevant biogeochemical parameters from the complete 1989-1994 LMER data set. Values to the right of each bar indicate the number of measurements averaged. Error bars represent $\pm 1 \mathrm{SE}$. Data for (c) to (g) from Cowen \& Boynton (1996) and W. Boynton (unpubl. data). Data for (k) from J. Cornwell (unpubl. data)
LB surface sediments, Large leathery worm tubes 110 to $20 \mathrm{~cm}$ in length), constructed by the suspensionfeeding polychaete Chaetopterus variopedatus (Nancy Mountford pers. comm.), were abundant in LB sediment. The tube ventilating activity of these polychaetes mixes oxygenated overlying bottom water to depth in the sediment, resulting in an oxidized benthic substrate (Fig. 2C). Both bioturbation at UB and worm tube ventilation at LB can have a significant effect on $\mathrm{O}_{2}$ penetration, redox potentials, solute and particle transport, and microbial metabolism in the local benthos (Revsbech et al. 1980, Hines et al. 1982, Aller \& Yingst 1985, Berner \& Westrich 1985, Kristensen \& Blackburn 1987).

Depth-integrated (0 to $12 \mathrm{~cm}$ ) $\mathrm{SO}_{4}{ }^{2-}$ pools increased from UB to LB (Fig. 2h), paralleling the trend in overlying water salinity (Fig. 2a). Average $\mathrm{SO}_{4}{ }^{2-}$ concentrations decreased rapidly with sediment depth at $M B$
(Fig. 3), and were often below the limit of detection $(2 \mu \mathrm{M})$ at depths $>10 \mathrm{~cm}$ during summer. In contrast, $\mathrm{SO}_{4}{ }^{2-}$ concentration remained nearly constant with depth at both UB and LB. Average pore water $\mathrm{HS}^{-}$at $\mathrm{MB}$ mirrored the trend in $\mathrm{SO}_{4}{ }^{2-}$, and increased from near zero at the sediment surface to $>2 \mathrm{mmol} \mathrm{l}^{-1}$ pore water below $10 \mathrm{~cm}$ (Fig. 3).

\section{Benthic sulfate reduction}

The complete Chesapeake Bay LMER data set for benthic SR rates and bottom water (incubation) temperatures is given in Table 1. Individually measured, monthly averaged, and model-predicted $\mathrm{SR}_{12}$ for the 3 benthic sites are depicted in Fig. 4. The spatial trend in $\mathrm{SR}$ was $\mathrm{MB}>\mathrm{LB}>\mathrm{UB}$ for all sampling dates. Rates at UB exhibited little seasonal trend and monthly aver- 
$\mathrm{SO}_{4}{ }^{2-}(\mathrm{mM})$
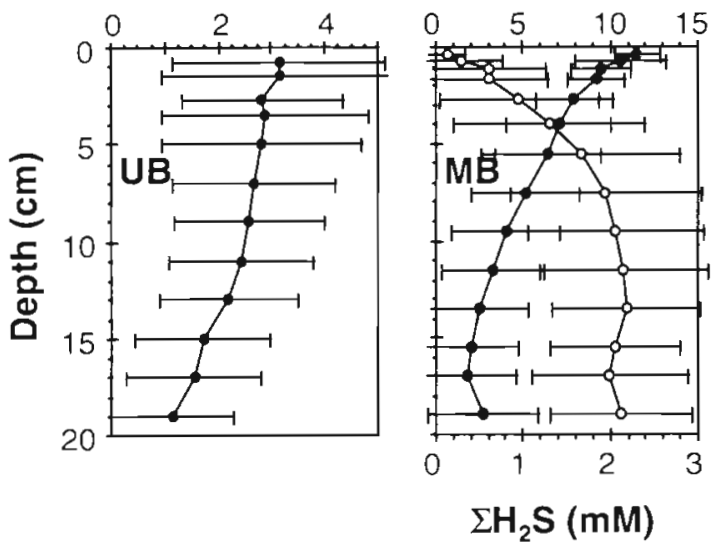

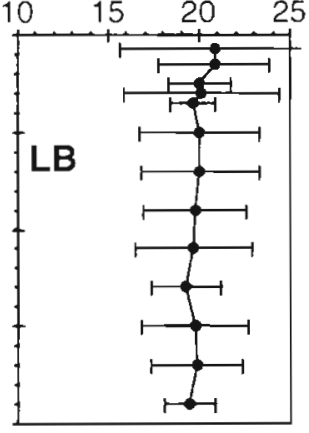

Fig. 3. Average pore water $\mathrm{SO}_{4}{ }^{2-}$ profiles for sites UB, MB and LB ( $\bullet$ ), and pore water $\Sigma \mathrm{H}_{2} \mathrm{~S}$ profile for MB only (0). Error bars represent $\pm 1 \mathrm{SD}$ ( $\mathrm{n}=11$ to 32 ). Note the differing scales for $\mathrm{SO}_{4}{ }^{2-}$ concentration

Table 1. Depth-integrated $(0$ to $12 \mathrm{~cm})$ sulfate reduction rates $\left(\mathrm{SR}_{12}, \mathrm{mmol} \mathrm{m} \mathrm{m}^{-2} \mathrm{~d}^{-1}\right)$ and bottom-water/incubation temperature $\left({ }^{\circ} \mathrm{C}\right)$ for the 1989-1994 Chesapeake Bay LMER program. Standard deviation (SD) represents $\mathrm{n}=2$ measurements, unless blank ( $\mathrm{n}=1$ )

\begin{tabular}{|c|c|c|c|c|c|c|c|c|c|c|c|}
\hline \multicolumn{4}{|c|}{ Site UB } & \multicolumn{4}{|c|}{ Site MB } & \multicolumn{4}{|c|}{ - Site LB } \\
\hline Date & ${ }^{\circ} \mathrm{C}$ & $\mathrm{SR}_{12}$ & $\mathrm{SD}$ & Date & ${ }^{\circ} \mathrm{C}$ & $\mathrm{SR}_{12}$ & SD & Date & ${ }^{\circ} \mathrm{C}$ & $\mathrm{SR}_{12}$ & $\mathrm{SD}$ \\
\hline \multicolumn{4}{|l|}{1989} & \multicolumn{4}{|l|}{1989} & \multicolumn{4}{|l|}{1989} \\
\hline $10 \mathrm{Mar}$ & 3 & 0.8 & 0.8 & $11 \mathrm{Mar}$ & 4 & 4.6 & 0.9 & & & & \\
\hline 18 Apr & 11 & 0.7 & & $19 \mathrm{Apr}$ & 9 & 4.8 & 0.8 & $20 \mathrm{Apr}$ & 11 & 5.8 & 0.2 \\
\hline 18 May & 12 & 0.8 & 0.2 & 19 May & 16 & 15.6 & 1.3 & $20 \mathrm{May}$ & 18 & 9.0 & 1.7 \\
\hline $07 \mathrm{Jun}$ & 23 & 10.8 & 1.2 & 08 Jun & 18 & 49.9 & 2.6 & 09 Jun & 22 & 28.8 & 5.7 \\
\hline $07 \mathrm{Jul}$ & 26 & 3.3 & 0.1 & $08 \mathrm{JuI}$ & 24 & 70.6 & 2.2 & $09 \mathrm{Jul}$ & 2.5 & 33.4 & 4.6 \\
\hline 07 Aug & 27 & 3.3 & 0.7 & 08 Aug & 25 & 46.2 & 2.0 & 09 Aug & 25 & 23.7 & 1.9 \\
\hline $07 \mathrm{Sep}$ & 25 & 6.9 & 1.3 & 08 Sep & 25 & 26.0 & 0.7 & $09 \mathrm{Sep}$ & 24 & 25.2 & 0.0 \\
\hline $14 \mathrm{Nov}$ & 13 & 2.1 & 0.1 & 15 Nov & 16 & 17.4 & 0.2 & & & & \\
\hline \multicolumn{4}{|l|}{1990} & \multicolumn{4}{|l|}{1990} & \multicolumn{4}{|l|}{1990} \\
\hline $17 \mathrm{Apr}$ & 13 & 1.3 & 0.0 & $18 \mathrm{Apr}$ & 10 & 1.5 .1 & 0.7 & $19 \mathrm{Apr}$ & 12 & 15.5 & 1.5 \\
\hline $04 \mathrm{Jun}$ & 17 & 0.6 & 0.0 & 08 Jun & 19 & 18.9 & 0.8 & 04 Jun & 17 & 19.2 & 5.6 \\
\hline \multirow[t]{2}{*}{$10 \mathrm{Jul}$} & \multirow[t]{2}{*}{28} & \multirow{2}{*}{\multicolumn{2}{|c|}{1.4}} & $11 \mathrm{Jul}$ & 24 & 32.5 & 1.1 & \multirow[t]{3}{*}{$12 \mathrm{Jul}$} & \multirow[t]{3}{*}{26} & \multirow[t]{3}{*}{29.2} & \multirow[t]{3}{*}{5.1} \\
\hline & & & & 02 Aug & 27 & 41.1 & & & & & \\
\hline 06 Nov & 12 & 2.3 & 0.1 & $07 \mathrm{Nov}$ & 16 & 17.2 & 1.7 & & & & \\
\hline \multicolumn{4}{|l|}{1991} & \multicolumn{4}{|l|}{1991} & \multicolumn{4}{|l|}{1991} \\
\hline $17 \mathrm{Apr}$ & 14 & 0.9 & 0.3 & $18 \mathrm{Apr}$ & 13 & 6.0 & & $19 \mathrm{Apr}$ & 13 & 6.0 & 1.5 \\
\hline \multirow[t]{2}{*}{27 May } & 26 & 3.9 & 1.4 & 28 May & 21 & 57.8 & 6.5 & \multirow[t]{2}{*}{29 May } & \multirow[t]{2}{*}{23} & \multirow[t]{2}{*}{38.6} & \multirow[t]{2}{*}{5.9} \\
\hline & & & & $10 \mathrm{Jun}$ & 23 & 70.4 & 2.8 & & & & \\
\hline $27 \mathrm{Jul}$ & 25 & 7.8 & 0.4 & $28 \mathrm{Jul}$ & 26 & 25.7 & 10.4 & 29 Jul & 26 & 44.1 & 7.5 \\
\hline & & & & $20 \mathrm{Aug}$ & 27 & 28.2 & 2.6 & & & & \\
\hline & & & & $16 \mathrm{Sep}$ & 26 & 33.9 & 15.7 & & & & \\
\hline 19 Nov & 12 & 3.3 & 1.6 & $20 \mathrm{Nov}$ & 14 & 10.6 & 1.0 & 21 Nov & 14 & 11.3 & 1.4 \\
\hline 1992 & & & & 1992 & & & & 1992 & & & \\
\hline & & & & 12 Mar & 6 & 9.0 & 1.3 & & & & \\
\hline $15 \mathrm{Apr}$ & 11 & 5.7 & 0.2 & $16 \mathrm{Apr}$ & 12 & 35.9 & 4.0 & $17 \mathrm{Apr}$ & 14 & 15.7 & 1.7 \\
\hline 14 Jul & 27 & 7.3 & 1.5 & $15 \mathrm{Jul}$ & 22 & 36.5 & 0.6 & $16 \mathrm{Jul}$ & 24 & 34.6 & 1.8 \\
\hline $08 \mathrm{Oct}$ & 18 & 4.8 & 0.5 & $08 \mathrm{Oct}$ & 19 & 15.6 & 2.5 & $09 \mathrm{Oct}$ & 20 & 20.8 & 0.8 \\
\hline 1993 & & & & 1993 & & & & 1993 & & & \\
\hline $20 \mathrm{Apr}$ & 12 & 2.5 & 0.6 & $19 \mathrm{Apr}$ & 10 & 19.7 & 2.7 & $20 \mathrm{Apr}$ & 12 & 18.6 & 2.6 \\
\hline 09 May & 21 & 1.5 & 0.0 & $08 \mathrm{May}$ & 13 & 15.5 & 1.9 & $12 \mathrm{May}$ & 14 & 14.4 & 1.7 \\
\hline $17 \mathrm{Jul}{ }^{\mathrm{d}}$ & 27 & 109.0 & 96.1 & $14 \mathrm{Jul}$ & 24 & 60.5 & 4.9 & $15 \mathrm{Jul}$ & 19 & 21.5 & 1.8 \\
\hline $18 \mathrm{Oct}$ & 18 & 4.4 & 0.8 & $19 \mathrm{Oct}$ & 19 & 30.3 & 6.4 & $20 \mathrm{Oct}$ & 19 & 21.3 & 4.6 \\
\hline 1994 & & & & 1994 & & & & 1994 & & & \\
\hline $06 \mathrm{Apr}$ & 14 & 2.3 & 0.6 & $07 \mathrm{Apr}$ & 12 & 48.3 & 8.7 & $08 \mathrm{Apr}$ & 12 & 10.1 & 1.0 \\
\hline $17 \mathrm{Jul}$ & 28 & 4.8 & 0.1 & $18 \mathrm{Jul}$ & 25 & 171.5 & 611 & $19 \mathrm{Jul}$ & 26 & 27.3 & 3.1 \\
\hline $15 \mathrm{Oct}$ & 17 & 4.2 & 0.2 & $16 \mathrm{Oct}$ & 17 & 20.6 & 0.4 & $17 \mathrm{Oct}$ & 17 & 14.0 & 1.6 \\
\hline
\end{tabular}



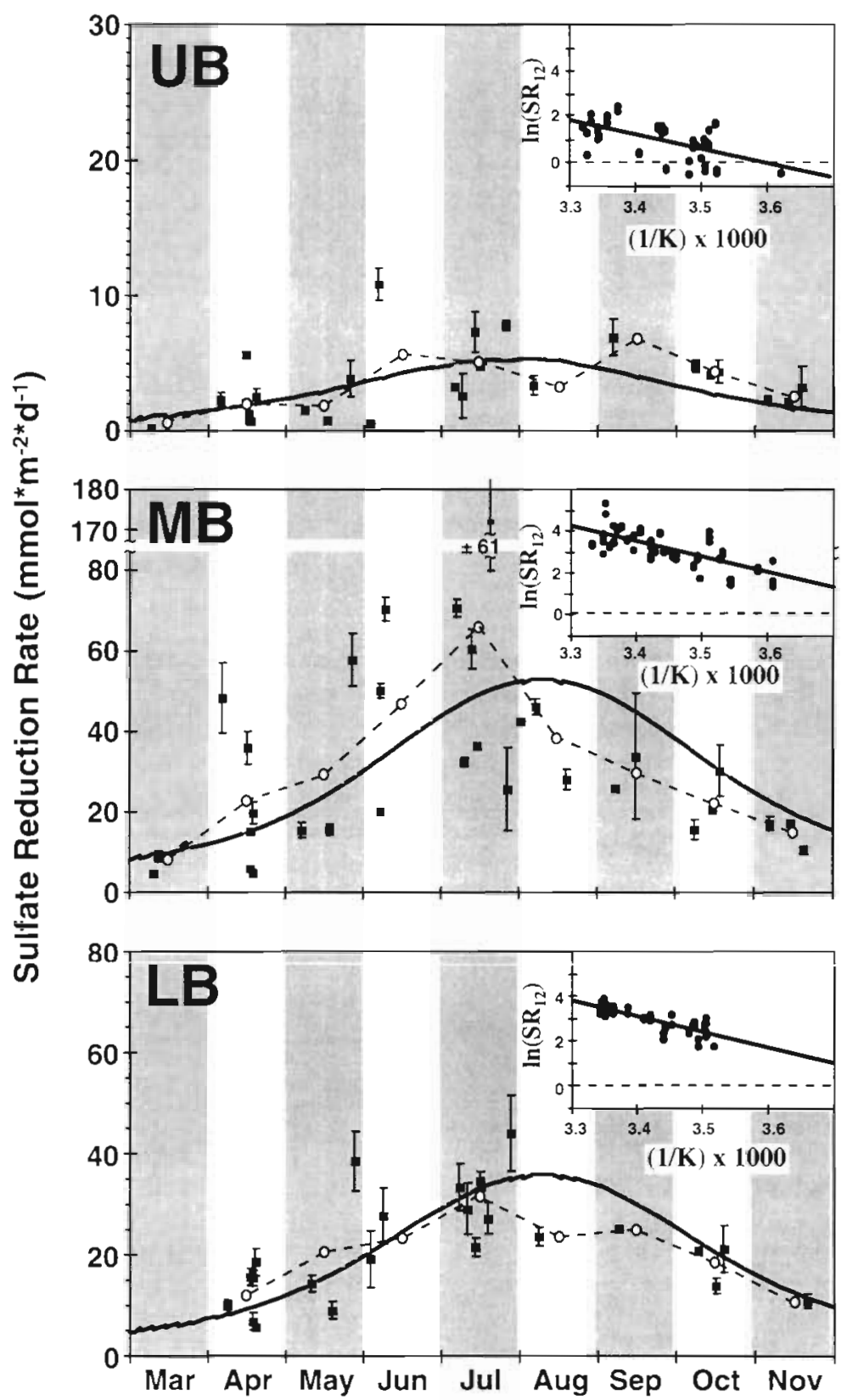

Fig. 4. 0-12 cm sulfate reduction rates $\left(\mathrm{SR}_{12}\right)$ versus Julian date (depicted as month interval) for all sampling dates ( $\mathbf{})$. Error bars represent $\pm 1 \mathrm{SD}$ $(\mathrm{n}=2)$. Monthly averages are indicated with o and dashed lines. Arrhenius/temperature model-predicted $\mathrm{SR}_{12}$ rate given as solid line. Arrhenius style plots $\left[\ln \left(\mathrm{SR}_{12}\right)\right.$ vs temp..$\left.^{-1}\right]$ used to calculate model parameters (Table 3) are inset for each site sites. A model-predicted $\mathrm{SR}$ rate maximum coinciding with the annual temperature maximum (August) was expected because the rate of SR, as predicted by Eq. (4), is based solely on temperature. Site-specific March-November SR rates calculated via Method B compared reasonably well with rates for the same period calculated via Method A (Table 2). This is not surprising as the 2 methods use the same data as a starting point, and thus are not completely independent of each other. However, Method A allowed for the propagation of error associated with each SR measurement, and subsequently for a direct error estimate for the March-November integrated rate. In contrast, while the error associated with the Arrhenius $C_{1}$ parameter is reported in Table 3, the use of this error in the calculation of temporally integrated SR rates was inappropriate, as it resulted in an unrealistically large propagated error. Hence, no error estimates are given for Method $\mathrm{B}$.

Based on the site-specific SR-temperature relationships determined by Method $B$ we were able to estimate SR rates during December-February, the period when no actual measurements were taken. Annual SR rates over a full year (January-December) were 8 to $11 \%$ greater (all sites) than the March-November integrated rates (Table 2). Thus, roughly $90 \%$ of total annual SR occurred during the spring through the fall. Annual-integrated $\mathrm{SR}_{2}$ rates accounted for roughly $10 \%$ (UB), $30 \%(\mathrm{MB})$, and $20 \%$ (LB) of the $\mathrm{SR}_{12}$ rates (Table 2). On average, SR was greatest at the sediment surface at $M B$ and was constant with depth at UB and LB (Fig. 5).

\section{Sulfate reduction and temperature}

The apparent influence of temperature on SR varied spatially, both among sites and with sediment depth. The spatial trend in site-specific $C_{t}$ and $A$ values $(\mathrm{LB}>\mathrm{MB}>$ ages ranged from 1 to $7 \mathrm{mmol} \mathrm{SO}_{4}{ }^{2-} \mathrm{m}^{-2} \mathrm{~d}^{-1}$. In contrast, $\mathrm{MB}$ and $\mathrm{LB}$ exhibited strong seasonal trends, with a range in monthly averages of 8 to $66 \mathrm{mmol} \mathrm{SO}_{4}{ }^{2-}$ $\mathrm{m}^{-2} \mathrm{~d}^{-1}$ and 11 to $32 \mathrm{mmol} \mathrm{SO}_{4}{ }^{2-} \mathrm{m}^{-2} \mathrm{~d}^{-1}$, respectively.

Model-predicted $\mathrm{SR}_{12}$ rates were maximal during August at $\mathrm{MB}$ and LB (Fig. 4). However, actual measured $\mathrm{SR}_{12}$ rates were maximal during July at both
$\mathrm{UB}$ ) paralleled each other for both $\mathrm{SR}_{2}$ and $\mathrm{SR}_{12}$ integration depths (Table 3 ). This trend was most pronounced in the surface $0-2 \mathrm{~cm}$ interval, which had a range in $C_{t}$ values of $39 \pm 17 \mathrm{~kJ} \mathrm{~mol}^{-1}$ (UB) to $88 \pm 13 \mathrm{~kJ}$ $\mathrm{mol}^{-1}$ (LB). The variability in rates due to the apparent temperature influence ranged from $10 \%$ (UB) to $52 \%$ (LB) for $\mathrm{SR}_{2}$, and $33 \%$ (UB) to $68 \%$ (LB) for $\mathrm{SR}_{12}$ based 
Table 2. Annual 0-2 cm and 0-12 cm depth-integrated SR rates ( $m o l ~ S O_{4}{ }^{2-} \mathrm{m}^{-2} \mathrm{yr}^{-1}$ ) for the 3 study sites, calculated from the sum of average monthly rates (Method A), and from the temperature-dependent Arrhenius model (Method B). Standard errors for Method $A$ are in parentheses. The " of $0-12 \mathrm{~cm} \mathrm{SR}\left(\mathrm{SR}_{12}\right)$ accounted for in the surface $0-2 \mathrm{~cm}$ interval is also given

\begin{tabular}{|c|c|c|c|c|c|}
\hline Site & Method & Time interval & \multicolumn{2}{|c|}{ Annual depth-integrated SR } & $\begin{array}{l}\% \text { of } S R_{12} \\
\text { in } 0-2 \mathrm{~cm}\end{array}$ \\
\hline UB & A & Mar-Nov & $0.12(0.00)$ & $1.01(0.10)$ & 12 \\
\hline$M B$ & A & Mar-Nov & $2.28(0.10)$ & $8.54(1.20)$ & 27 \\
\hline LB & A & Apr-Nov & $1.14(0.02)$ & $5.09(0.24)$ & 22 \\
\hline UB & B & Mar-Nov & 0.08 & 0.88 & 9 \\
\hline $\mathrm{MB}$ & B & Mar-Nov & 2.96 & 8.56 & 34 \\
\hline LB & $B^{\dot{a}}$ & Mar-Nov & 1.07 & 5.66 & 19 \\
\hline UB & $\mathrm{B}^{\mathrm{b}}$ & Jan-Dec & 0.09 & 0.96 & 9 \\
\hline$M B$ & $\mathrm{~B}^{\mathrm{b}}$ & Jan-Dec & 3.20 & 9.62 & 33 \\
\hline $\mathrm{LB}$ & $B^{b}$ & Jan-Dec & 1.13 & 6.33 & 18 \\
\hline \multicolumn{6}{|c|}{$\begin{array}{l}\text { "Estimated using the March temperatures predicted from the temperature model (Eq. 3) curve fit to the combined MB } \\
\text { and LB temperature data } \\
\text { 'Estimated by assumıng a minimum temperature of } 3^{\circ} \mathrm{C} \text { on February 1. Daily temperatures between February } 1 \text { and } \\
\text { the } 2 \text { model endpoints (March } 1 \text { and November } 31 \text { ) were calculated by linear interpolation. SR rates from November } 31 \\
\text { through March } 1 \text { were then calculated using in Eq. (4) and Arrhenius parameters (Table 3) }\end{array}$} \\
\hline
\end{tabular}

Table 3. Site-specific temperature characteristic $\left(C_{i}\right)$ and preexponential factor $(A)$ values calculated by fitting the Arrhenius style linear regression (Eq. 4) to the $0-2 \mathrm{~cm}$ and $0-12 \mathrm{~cm}$ depth-integrated SR rate and temperature data. The regression $\mathrm{r}^{2}$ is also shown. $C_{1}$ standard errors, given in parentheses, were calculated from the regression coefficient

\begin{tabular}{|lcccc|}
\hline Site & $\begin{array}{c}\text { Integration } \\
\text { depth }(\mathrm{cm})\end{array}$ & $\begin{array}{c}C_{r} \\
\left(\mathrm{~kJ} \mathrm{~mol}^{-1}\right)\end{array}$ & $\mathcal{A}$ & $\mathrm{r}^{2}$ \\
\hline UB & $0-2$ & $39(17)$ & $2.8 \times 10^{6}$ & 0.10 \\
MB & $0-2$ & $57(10)$ & $1.3 \times 10^{11}$ & 0.46 \\
LB & $0-2$ & $88(13)$ & $1.8 \times 10^{16}$ & 0.52 \\
UB & $0-12$ & $49(11)$ & $2.1 \times 10^{9}$ & 0.33 \\
MB & $0-12$ & $56(9)$ & $2.5 \times 10^{11}$ & 0.42 \\
L.B & $0-12$ & $59(6)$ & $6.2 \times 10^{11}$ & 0.68 \\
\hline
\end{tabular}

on $r^{2}$ values (Table 3 ). $C_{t}$ and $A$ values were also calculated for all discrete $2 \mathrm{~cm}$ intervals, from 0 to $12 \mathrm{~cm}$, to discern the apparent temperature influence on SR with increasing sediment depth. (Fig. 6). The vertical trend in $A$ paralleled that of $C_{1}$ and no significant differences were observed in either parameter with increasing depth at either UB or MB. However, a significant $(p<0.05)$ decrease in $C_{t}$ was observed from the $0-2 \mathrm{~cm}$ to the $4-6 \mathrm{~cm}$ interval at $L B$.

\section{Reduced sulfur}

UB had the largest TRS pool size among the 3 study sites (Fig. 2i) even though SR rates were the lowest at this location (Table 1). The concentration of in situ

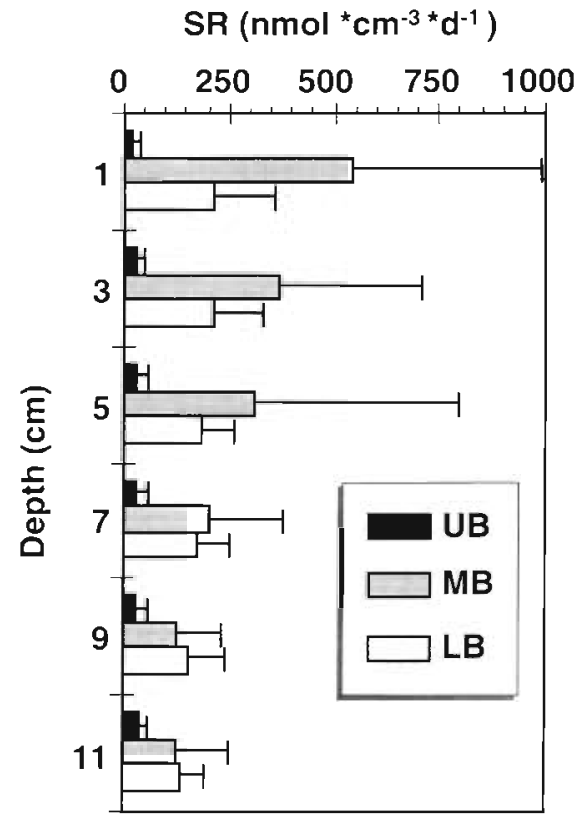

Fig. 5. Average of all (1989-1994) sulfate reduction (SR) depth profiles for the 3 study sites. The $y$-axis depicts the mid-point depth for each $2 \mathrm{~cm}$ interval. Error bars represent $\pm 1 \mathrm{SD}$ ( $\mathrm{n}=$ 23 to 34 )

NAVS (assumed to be primarily $\mathrm{FeS}_{2}$ ) exceeded AVS (assumed to be primarily $\mathrm{H}_{2} \mathrm{~S}$ and FeS) at all sites (Fig. 7a-f). UB exhibited an average NAVS mid-depth maximum, while this fraction linearly increased with depth at both MB and LB (Fig. $7 \mathrm{a}-\mathrm{C}$ ). The relative amounts of AVS and NAVS were fairly constant 

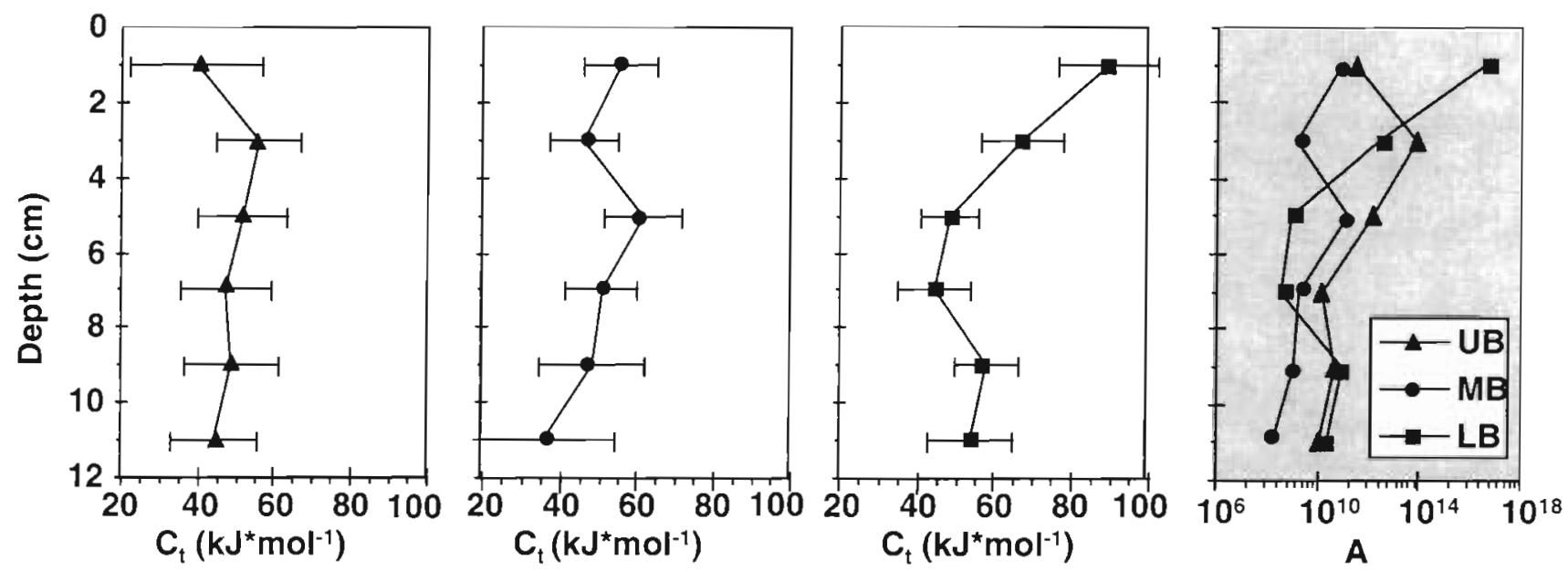

Fig. 6. Sediment depth profiles of $C_{l}$ and $A$ values (from Eq. 4), calculated using all sulfate reduction and temperature data. $C_{t}$ error bars, representing $\pm 1 \mathrm{SE}$, were calculated from the regression coefficient

throughout the averaged profiles, with NAVS contributing $\sim 75 \%$ to the TRS pool at both $\mathrm{UB}$ and $\mathrm{MB}$, and $-90 \%$ at LB (Fig. $7 \mathrm{~d}-\mathrm{f}$ ). The fraction of $\mathrm{TR}^{35} \mathrm{~S}$ recovered as $\mathrm{AV}^{35} \mathrm{~S}$, after $4 \mathrm{~h}$ incubations, ranged from 38 to $67 \%$ (UB), 64 to $84 \%$ (MB), and 65 to $73 \%$ (LB) for all depth intervals (Fig. $7 \mathrm{~g}-\mathrm{i}$ ). Only in the $0-2 \mathrm{~cm}$ sediment interval at $\mathrm{UB}$ did the recovery of $\mathrm{NAV}^{35} \mathrm{~S}$ exceed AV ${ }^{35}$ S.

\section{DISCUSSION}

\section{Spatial controls on benthic sulfate reduction}

The Chesapeake Bay LMER database provides a detailed description of both spatial and temporal variation in benthic SR for a complex temperate estuary (Table 1). A systematic approach is needed to resolve the time and space components of this robust data set. We begin here by assessing which factors limit benthic SR (i.e. electron acceptor or donor availability), spatially, at the 3 contrasting study sites. We focus on annually integrated SR rates (Table 2) and averaged site-specific biogeochemical data (Fig. 2) to do this, while largely omitting temporal considerations in the current discussion. A quantitative assessment of the temporal trends and controls on benthic SR will be addressed in a future publication.

Sulfate-reducing bacteria (SRB) in freshwater and oligohaline estuarine sediments, where $\mathrm{SO}_{4}{ }^{2-}$ concentration is typically low, may exhibit a greater affinity for $\mathrm{SO}_{4}{ }^{2-}$ than do populations of $\mathrm{SRB}$ acclimated to higher concentrations (Lovley \& Klug 1983, Roden \& Tuttle 1993b), Roden \& Tuttle (1993b) measured an apparent half-saturating $\mathrm{SO}_{4}{ }^{2-}$ pore water concentra- tion $\left(K_{\mathrm{s}}\right)$ of $34 \mu \mathrm{M}$ for an oligohaline site 6.3 nautical miles northeast of $\mathrm{UB}$, and $K_{\mathrm{s}}$ values of 920 to $950 \mu \mathrm{M}$ $\mathrm{SO}_{4}{ }^{2-}$ for a mesohaline site. In the current study, pore water $\mathrm{SO}_{4}{ }^{2-}$ was consistently $>400 \mu \mathrm{M}$ in the top $12 \mathrm{~cm}$ of UB sediment, with an average of $2.8 \pm 1.8 \mathrm{mM}$. It is reasonable to assume the SRB populations at UB more closely resembled populations in Roden \& Tuttle's nearby oligohaline site than mesohaline SRR populations. This implies that $\mathrm{SO}_{4}{ }^{2-}$ concentration did not limit SR at UB, assuming similar $K_{\mathrm{s}}$ values among the 2 oligohaline sites. Thus, $C$ limitation was responsible for the low SR rates at UB. This is supported by the PC/PN (Fig. 2e) and $\delta^{13} \mathrm{C}$ (Fig. $2 \mathrm{k}$ ) data which confirm that much of the organic deposition at UB is refractory terrestrial material. The UB sediment surface was more susceptible to wind and high river flow induced resuspension events, relative to $M B$ and $L B$, due to both its shallower water column depth and its proximity to the Susquehanna River. Continuous resuspension and deposition of degrading organic material may have limited the amount of organic $C$ buried below the aerobic sediment surface, and facilitated aerobic respiration of this material within the shallow UB water column (Smith \& Kemp 1995) and benthic boundary layer. A large fraction of the phytoplankton produced in the oligohaline, region also may have been transported further down-bay, during periods of high river flow, and deposited in the mesohaline (Biggs \& Flemer 1972). Thus, organic quality, aerobic respiration of labile organic matter, and abiotic physical processes all may have played a role in the C limitation of benthic SR at UB.

The near vertical depth profile of average SR at UB (Fig. 5), and similar vertical profiles from individual sampling dates (not shown), implies that the degree of 

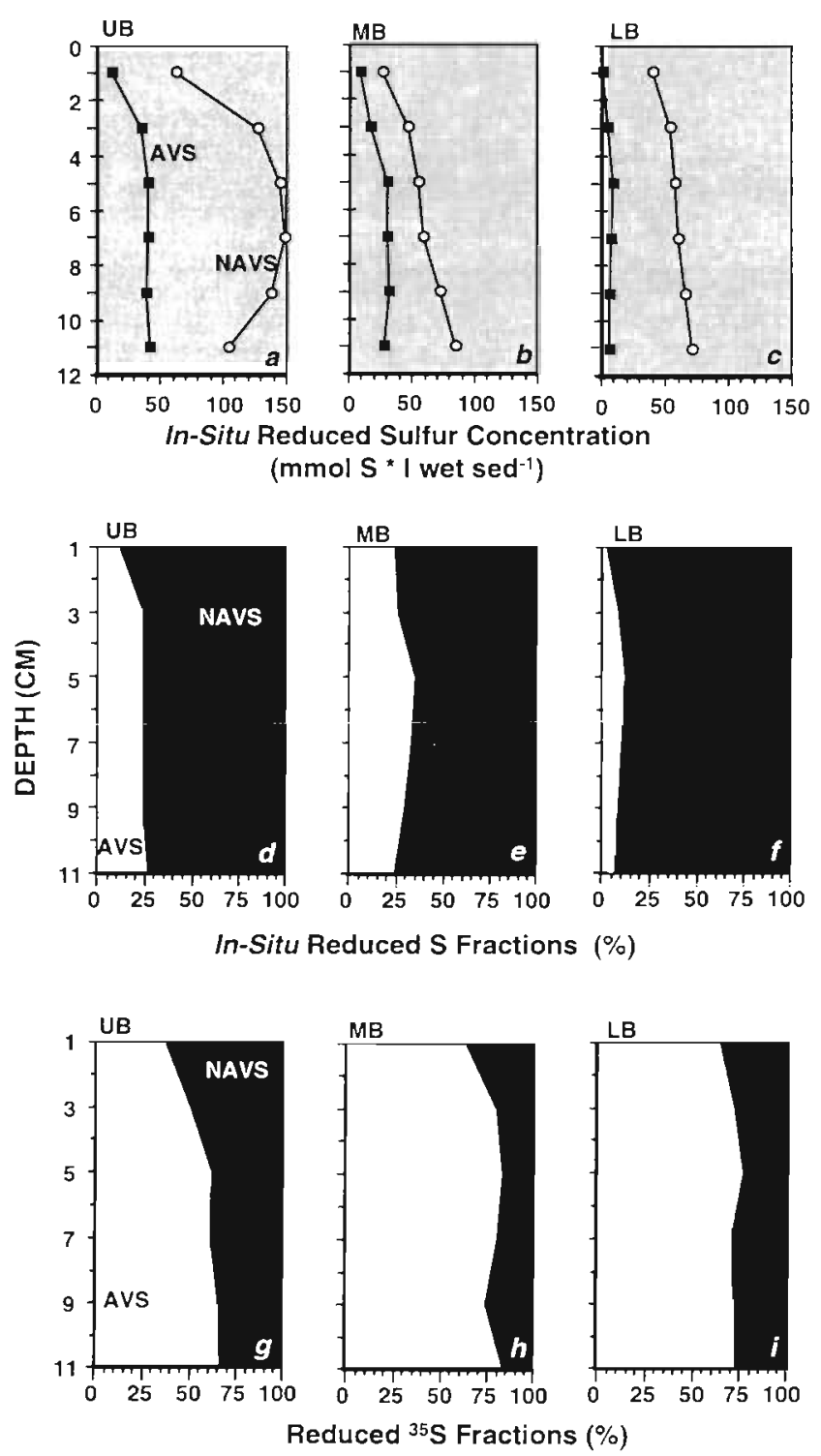

Fig. 7 Sediment depth profiles of acid volatile sulfur (AVS) and non-acid volitile sulfur (NAVS) for the 3 LMER benthic sites, depicted in terms of in situ concentration (a to c), the percentage of total reduced sulfur ( $d$ to $\mathrm{f}$ ), and the percentage of reduced- ${ }^{35} \mathrm{~S}$ end product measured in each fraction ( $g$ to $\mathrm{i}$ ) after $4 \mathrm{~h}$ incubation. All profiles represent the average of 6 separate sampling dates

C limitation of SR was essentially constant with depth. This was attributed to bioturbation by the resident macrofauna community, which mixes fresh POM below the sediment/water interface, partially homogenizes the mixed layer with respect to organic quality, and fuels anaerobic metabolism at depth (Blair et al. 1996)

The $\mathrm{MB}$ average $0-4 \mathrm{~cm}$ pore water $\mathrm{SO}_{4}{ }^{2-}$ concentration was $9.4 \pm 3.0 \mathrm{mM}$, which was an order of magnitude greater than the $K_{\varsigma}$ value of $0.9 \mathrm{mM}$ calculated for SR in mesohaline Chesapeake Bay sediments
(Roden \& Tuttle 1993b), and also exceeded the $K_{\mathrm{s}}$ (1.6 $\mathrm{mM} \mathrm{SO}_{4}{ }^{2-}$ ) calculated for Long Island Sound marine sediments (Boudreau \& Westrich 1984). However, $\mathrm{SO}_{4}{ }^{2-}$ concentrations below $8 \mathrm{~cm}$ were often less than $0.9 \mathrm{mM}$, or below detection $(<2 \mu \mathrm{M})$, as $\mathrm{SO}_{4}{ }^{2-}$ invariably decreased with sediment depth (Fig. 3). This implies that at $\mathrm{MB}, \mathrm{SR}$ was often $\mathrm{SO}_{4}{ }^{2-}$ limited at depth, but not at the sediment surface.

The peak in $\mathrm{MB} \mathrm{SR}_{12}$ during July followed the deposition of the spring phytoplankton bloom, which typically occurs in April-May (Malone et al. 1988), but preceded the annual temperature maximum during August (Fig. 4). A similar early summer maximum in $\mathrm{SR}_{12}$ rates was reported for site $\mathrm{R} 64(<0.5 \mathrm{~km}$ from $\mathrm{MB})$ and at another mid-bay flank station (Roden \& Tuttle 1993a, Roden et al. 1995). Cowen \& Boynton (1996) also reported a July peak in $\mathrm{NH}_{4}{ }^{+}$flux at $\mathrm{MB}$. In all cases, the timing of these peak rates was attributed to the response of the benthic microbial community to freshly deposited organic matter associated with the spring bloom. In lieu of bioturbation at $\mathrm{MB}$, the precipitous decline in measured rates after. July (Fing 4) indicated that much of this material was consumed at the sediment surface. This is supported by the disproportionate fraction ( $33 \%$ ) of annual $\mathrm{SR}_{12}$ which took place in the top 0-2 cm sediment interval (Table 2). We conclude that $C$ availability limited SR in MB surface sediments.

At LB, SR was limited by labile organic $C$ at all depths, as evident by the high pore water $\mathrm{SO}_{4}{ }^{2-}$ concentration (>15 mM) throughout the top $20 \mathrm{~cm}$ (Fig. 3), and the lower values for indices of deposited organic matter [PC (Fig. 2d), PN (Fig. 2e), chl a (Fig. 2g), and TOM (Fig. 2j)], relative to MB. As with UB, macrofaunal activity at LB likely accounted for the near vertical trend in the average SR rate profile (Fig. 5). While both $\mathrm{UB}$ and LB were C limited, SR was consistently higher at LB (Table 1). This was presumably due to the differing sources of deposited organic matter, with the larger fraction of terrestrial input at UB associated with low rates relative to the phytoplankton $C$ dominated LB, even though the absolute amount of organic loading at UB exceeded that at LB (Fig. 2d, e, j). Thus, the quality of organic loading in estuarine systems may play a more important role than the absolute amount of organic loading in dictating the spatial differences in benthic SR rates.

\section{Sulfate reduction and temperature}

The $C_{\text {f }}$ values calculated for the 3 study sites (Table 3) fall within the range 36 to $98 \mathrm{~kJ} \mathrm{~mol}^{-1}$ reported for other coastal marine systems /Crill \& Martens 1987, King 1988, Westrich \& Berner 1988, Ro- 
den \& Tuttle 1993a), as calculated from annual SR field data at in situ incubation temperatures. The $\mathrm{C}_{t}$ at $\mathrm{MB}$ (56 $\pm 9 \mathrm{~kJ} \mathrm{~mol}^{-1}$, Table 3 ) was considerably lower than the 81 to $87 \mathrm{~kJ} \mathrm{~mol}^{-1}$ calculated for Chesapeake mesohaline sediments by Roden \& Tuttle (1993a). The Arrhenius function was better fit to this earlier data set $\left(r^{2}=0.76, n=9\right)$ than to our current data $\left(r^{2}=0.42, n=\right.$ 32). The observed differences in the response of SR to temperature among the 2 studies may reflect either actual among-site (spatial) differences, or differences in sampling intensity (i.e. temporal heterogeneity).

Spatial variations in the apparent temperature response of SR were most pronounced at the sediment surface (Table 3, Fig. 6). The similar spatial trends in both regression parameters, $C_{t}$ and $A$, indicate that either may serve as a relative index of the apparent response of $\mathrm{SR}$ to temperature. However, $C_{l}$ is the parameter most often used for this assessment. The poor fit of the Arrhenius model to the UB SR data $\left(\mathrm{r}^{2}=\right.$ $0.1)$ may reflect variations in the degree of reduced-S reoxidation, and thus temporally variable underestimates of $\mathrm{SR}$, in this surface interval throughout the year (see below). The high $0-2 \mathrm{~cm} C_{t}$ observed for LB, compared with $\mathrm{MB}$, may reflect differences in substrate availability and/or sediment redox conditions, which could lead to differences in the SRB community composition, and thus differences in $C_{t}$ values observed among sites (Roden \& Tuttle 1993b). Westrich \& Berner (1988) noted a general increase in $E_{\mathrm{a}}$ with sediment depth over a much deeper interval $(0$ to $140 \mathrm{~cm}$ ), and observed that decreasing SR rates were correlated with increasing $E_{a}$ values. They attributed this trend to differences in the quality and/or availability of organic substrate among sites. This may in part explain the apparent stronger response of SR to temperature at LB compared to MB (Table 3, Fig. 6), as SR rates were always greater at $\mathrm{MB}$ for any given temperature (Table 1). However, this does not explain the decrease in $C_{t}$ values with sediment depth at LB (Fig. 6), as SR rates remained essentially constant with depth at this site (Fig. 5). Differences in the SRB community composition with depth could account for this trend (Roden \& Tuttle 1993b). Alternatively, increasing temperatures typically lead to increased microbial respiration rates and hypoxia. This in turn leads to increased rates of worm tube ventilation to compensate for the low oxygen conditions (Forster et al. 1995), and subsequently to increased rates of $\mathrm{SR}$ due to enhanced macrofauna activity (Hines et al. 1982, Hines \& Jones 1985). Thus, the higher $C$, values at the LB surface sediment ultimately may reflect the effect of temperature on macrofaunal processes which in turn impact SR rates throughout the year. Thus, the apparent influence of temperature on SR is mediated by the interaction of multiple factors, such as organic quality and quantity, sediment redox conditions and macrofauna activity, all of which vary along the estuarine gradient.

\section{Reduced sulfur pool size and burial}

The large NAVS pool size, relative to AVS, observed at all sites and depths (Fig. $7 \mathrm{a}-\mathrm{f}$ ) is a common feature of marine sediments (Fallon 1987. Swider \& Mackin 1989, Roden \& Tuttle 1993b). This results from NAVS (primarily $\mathrm{FeS}_{2}$; Morse \& Cornwell 1987) being thermodynamically more stable than the readily reoxidized AVS ( $\mathrm{H}_{2} \mathrm{~S}$ and FeS) fraction (Kaplan et al. 1963). While greater than $50 \%$ of $\mathrm{TR}^{35} \mathrm{~S}$ was typically recovered as $\mathrm{AV}^{35} \mathrm{~S}$ after $4 \mathrm{~h}^{35} \mathrm{SO}_{4}{ }^{2-}$ incubations (Fig. $7 \mathrm{~g}-\mathrm{i}$ ), a substantial fraction (16 to $62 \%$ ) was recovered as $\mathrm{NAV}^{35} \mathrm{~S}$. This was indicative of rapid $\mathrm{FeS}_{2}$ formation via SR (Howarth 1979, Howarth \& Jørgensen 1984). Roden \& Tuttle (1993a) reported recoveries of 20 to $40 \%$ of $\mathrm{TR}^{35} \mathrm{~S}$ as $\mathrm{NAV}^{35} \mathrm{~S}$ for $0-2 \mathrm{~cm}$ mesohaline sediment (site R64), which compares well with our observed average of $36 \%$ for the same interval at $\mathrm{MB}$. Only in UB surface sediment did $\mathrm{NAV}^{35} \mathrm{~S}$ recoveries exceed $\mathrm{AV}^{35} \mathrm{~S}$ (Fig. $7 \mathrm{~g}$ ). This was presumably linked to high concentrations of reactive iron-(hydr)oxides in the oligohaline region (>300 $\mu \mathrm{mol} \mathrm{g}^{-1}$ dry sed.) compared to further down-bay ( $\leq 150 \mathrm{umal} \mathrm{g}^{-1}$ dry sed.) (Cornwell \& Sampou 1995). High concentrations of reduced Fe $(\sim 300 \mu \mathrm{M})$ in pore water during spring (Burdige 1993) and summer ( 40 $\mu \mathrm{M}$ ) (Cornwell \& Sampou 1995) have been reported for site UB. This, in addition to the presence of reduced $\mathrm{Mn}$ ( 150 $\mathrm{MM}$ during spring; Burdige 1993), suggests that dissimilatory Fe and Mn reduction may also play a role in degradation of organic matter in the oligohaline reaches of Chesapeake Bay. As a result, $\mathrm{Fe}^{2+}$ appears to be readily available to react with any sulfide produced via SR, which presumably results in the rapid formation of FeS. Further, the reaction of metastable FeS with additional sulfide to form $\mathrm{FeS}_{2}$ and $\mathrm{SO}_{4}{ }^{2-}$ has been linked to the availability of oxidants (e.g. $\mathrm{O}_{2}, \mathrm{MnO}_{2}, \mathrm{NO}_{3}{ }^{-}$) transported to depth in sediment by biotic and/or abiotic physical mixing events (Swider \& Mackin 1989). Both types of physical mixing are common at UB. Enhanced trapping of microbially reduced-S as Fe-S minerals at UB was also reflected in the large TRS pool at this site compared to MB and LB (Fig. 2i). This UB TRS pool was also larger than that previously measured at another oligohaline Chesapeake Bay site further north (Roden \& Tuttle 1993b), primarily due to higher NAVS concentrations at UB (60 to $150 \mathrm{mmol}^{-1}$ wet sed.) compared to the upestuary site (10 to $25 \mathrm{mmol} \mathrm{l}^{-1}$ wet sed.). AVS concentrations were similar among both locations (15 to $25 \mathrm{mmol}^{-1}$ wet sed.). 
To estimate $\mathrm{S}$ burial among sites, we first assumed that only the NAVS fraction was permanently buried. Using the average NAVS concentration from the $10-12 \mathrm{~cm}$ interval (Fig. $7 \mathrm{a}-\mathrm{c}$ ) and sedimentation rates of 0.7 (UB) and 0.5 (MB and LB) $\mathrm{cm} \mathrm{yr}^{-1}$ (Owens \& Cornwell 1995, Cornwell et al. 1996), we calculated NAVS burial rates of 0.73 (UB), 0.43 (MB), and $0.36(\mathrm{LB}) \mathrm{mol} \mathrm{S} \mathrm{m}^{-2} \mathrm{yr}^{-1}$, which correspond to 76,4 , and $6 \%$, respectively, of $\mathrm{SO}_{4}{ }^{2-}$ reduced annually (via Method B, Table 2). If we assume both AVS and NAVS fractions were buried, our above estimates increase to $1.13(\mathrm{UB}), 0.57(\mathrm{MB})$, and 0.51 (LB) $\mathrm{mol} \mathrm{S} \mathrm{m}^{-2} \mathrm{yr}^{-1}$ or 118 (UB), 6 (MB), and $8 \%$ (LB) of annual SR. Roden et al. (1995) similarly used $10-12 \mathrm{~cm}$ TRS to calculated a burial rate of $0.56 \mathrm{~mol} \mathrm{~S} \mathrm{~m} \mathrm{~m}^{-2} \mathrm{yr}^{-1}$ at site $\mathrm{R} 64$, which agrees with our $\mathrm{MB}$ estimate.

Our above estimates, based on 10-12 cm TRS concentrations, suggest that more $\mathrm{S}$ was buried at UB than was produced via SR. Our first estimate $(76 \%$ burial of $S$ reduced annually), based on NAVS only, was very similar to the percentage reported $(77 \pm 19 \%$ burial of $S$ reduced annually) for Cape Lookout Bight sediments (North Carolina, USA; Chanton et al. 1987). However, exceptionally high sedimentation rates $\left(10 \mathrm{~cm} \mathrm{yr}^{-1}\right)$ and a lack of bioturbation accounted for the high burial rates in that system. Neither of these factors could explain the high burial rates calculated for UB. A more likely explanation is that our annual SR rate for UB was underestimated due to reduced- ${ }^{35} \mathrm{~S}$ reoxidation during the ${ }^{35} \mathrm{SO}_{4}{ }^{2-}$ incubation (Fossing \& Jørgensen 1990). This was observed for ${ }^{35} \mathrm{SO}_{4}{ }^{2-}$ incubations in excess of $3 \mathrm{~h}$ for Chesapeake Bay oligohaline sediments collected north of UB (Roden \& Tuttle 1993b). The large fraction of $T^{35} \mathrm{~S}$ recovered as $\mathrm{NAV}^{35} \mathrm{~S}$ suggests that sulfide reoxidation at UB may have been linked to rapid pyrite formation (Swider \& Mackin 1989). Alternatively, sulfide reoxidation may have been linked to abiotic iron-(hydr)oxide reduction (Wilkin \& Barnes 1996), or to the microbial disproportionation of thiosulfate $\left(\mathrm{S}_{2} \mathrm{O}_{3}{ }^{2-}\right.$ ) (Jørgensen 1990, Jørgensen \& Bak 1991) or elemental $\mathrm{S}^{0}$ (Thamdrup et al. 1993, Finster et al. 1998) to $\mathrm{SO}_{4}{ }^{2-}$ and sulfide. As the actual amount of reduced ${ }^{35} \mathrm{~S}$ reoxidation during the incubation can only be assessed with detailed SR time course measurements (Moeslund et al. 1994), we are unable to directly quantify this for site UB. However, Moeslund et al. (1994) determined that SR was underestimated by 5 -fold in Aarhus Bay (Denmark) surface sediments $(0-1.5 \mathrm{~cm})$ due to reduced-S reoxidation, but was not underestimated at depth. If we assume a similar 5-fold underestimation for $0-2 \mathrm{~cm}$ surface sediments at UB, and no significant reoxidation below this depth, our estimate of annual $\mathrm{SR}_{12}$ increases $30 \%$ from 1.0 to 1.3 $\mathrm{mol} \mathrm{SO}{ }_{4}{ }^{2-} \mathrm{m}^{-2} \mathrm{Yr}^{-1}$, and our estimate of reduced-S burial decreases from $76 \%$ to $56 \%$ of annual SR. Addi- tional factors that could account for an overestimation of burial rates include (1) an overestimation of the sedimentation rate or TRS pool size, (2) the input and burial of additional Fe-S minerals formed external to UB or (3) the incorporation of reduced ${ }^{35} \mathrm{~S}$ species into the organic-S compounds that would not have been accounted for in either the inorganic $A V^{35} S$ or $N A V^{35} S$ fractions. We do not believe that any of these potential factors were significant, and, without evidence to the contrary, we conclude that $>50 \%$ of $\mathrm{S}$ reduced annually is permanently buried at UB.

The low percentage of reduced-S burial at $M B$ and LB suggest that the majority of reduced-S was ultimately reoxidized at these sites. Sediment profiles given both by Burdige (1993) and Cornwell \& Sampou (1995) for the 3 benthic LMER sites indicate that MB had the highest concentration of dissolved $F e$ in pore water, reaching levels of 300 to $1000 \mu \mathrm{M}$ in the $1-3 \mathrm{~cm}$ depth horizon during spring. Pore water $\mathrm{Mn}$ also exhibited a concentration maximum $(300 \mu \mathrm{M})$ in the same horizon (Burdige 1993). These observations sugqest that, at least during the spring, the reoxidation of sulfide, and/or intermediate reduced-S species (i.e. $\mathrm{S}^{0}$ and $\mathrm{S}_{2} \mathrm{O}_{3}{ }^{2-}$ ), to $\mathrm{SO}_{4}{ }^{2-}$ may be linked to the reduction of Fe and Mn oxides at MB (Burdige 1993, Thamdrup et al. 1993). The subsurface maximum in pore water $\mathrm{Fe}$ was no longer evident by August, and the nearly vertical profile exhibited concentrations much lower (<50 $\mu \mathrm{M}$ ) than during spring (Cornwell \& Sampou 1995). Enhanced sulfide stripping, due to $\mathrm{CH}_{4}$ bubble ebullition, has also been previously suggested for mesohaline Chesapeake Bay sediments (Roden \& Tuttle 1992). Our observations support this, as bubble pockets were often evident in MB cores, particularly during mid-summer through the fall. In addition to this advective transport, sulfide may passively diffuse across the sediment water interface as concentrations in the sediment build and the redox boundary layer moves into the water column during the warm season. Thus, during the summer and fall, much of the free sulfide in the mesohaline may be reoxidized in the overlying water column as opposed to in the sediment. At UB and $L B$, the lack of both visible bubble pockets and measurable free sulfide, as well as sub-saturating levels of dissolved $\mathrm{CH}_{4}$ (Marvin-DiPasquale unpubl. data), suggest that neither diffusion nor bubble ebullition resulted in a significant loss of free sulfide at these 2 sites, and that any reoxidation which occurred did so in the sediment.

It has been suggested that in organic-rich anoxic sediments, like $M B$, pyrite formation may be limited by enhanced Fe-(hydr)oxide dissolution and the mitigation of pyrite nucleation and growth due to organic complexation of reactive iron (Morse \& Wang 1997). Similar low burial rates $(\sim 5 \%)$ have been observed in 
organic-rich salt marsh sediments (Swider \& Mackin 1989). This may also partially explain the low fraction of reduced-S burial at $\mathrm{MB}$

March profiles given by Burdige (1993) show pore water concentrations of $\mathrm{Mn}$ linearly increasing to $\sim 75 \mu \mathrm{M}$ and an Fe maximum $(\sim 150 \mu \mathrm{M})$ in the $2-3 \mathrm{~cm}$ depth horizon at site LB. During August, the subsurface maximum in $\mathrm{Fe}(-100 \mu \mathrm{M}$ at $1 \mathrm{~cm}$ below the surface) was still evident, along with a corresponding maximum in pore water $\mathrm{SO}_{4}{ }^{2-}$ in the same horizon (Cornwell \& Sampou 1995). These observations suggest that the reduction of $\mathrm{Fe}$ and $\mathrm{Mn}$ oxides may also play a role in reduced-S oxidation in the sandy polyhaline portion of Chesapeake Bay.

\section{Annual primary production mineralization via benthic SR}

Benthic SR mineralized a substantial fraction of annual primary production. Kemp et al. (1997) recently calculated annual gross primary production for the Chesapeake Bay mainstem from $\mathrm{O}_{2}$ production data collected as part of the LMER program. For the pelagic zone this was 125 (upper-), 714 (mid-), and 730 (lowerBay) $\mathrm{g} \mathrm{C} \mathrm{m}^{-2} \mathrm{yr}^{-1}$ (calculated from data in Table 1 of Kemp et al. 1997). From annual $\mathrm{SR}_{12}$ rates (via Method $B$, Table 2), we calculate that SR mineralized $18 \%$ (UB), $32 \%(\mathrm{MB})$, and $21 \%$ (LB) of annual autochthonous organic production, assuming 2 moles of organic matter $\left(\mathrm{CH}_{2} \mathrm{O}\right)$ were oxidized per mole of $\mathrm{SO}_{4}{ }^{2-}$ reduced (Jørgensen 1977). If our $\mathrm{SR}_{12}$ rate for $\mathrm{UB}$ is underestimated by $\sim 30 \%$, as argued above, the amount of annual production consumed via SR at this site increases from $18 \%$ to $25 \%$. Our MB estimate compares well with that of Roden et al. (1995) who reported 30 to $35 \%$ of annual production was mineralized via SR in the mesohaline Chesapeake Bay. Our lower estimates for both the UB and LB suggest that aerobic respiration may play a larger role in phytoplankton consumption at these bioirrigated locations, relative to the non-bioturbated $\mathrm{MB}$. A comparison of LMER sediment oxygen consumption (SOC) and SR data suggests that aerobic respiration accounted for a larger fraction of benthic respiration than did SR at site UB, but not at LB or MB (Kemp et al. 1997). However, in light of the high concentrations of reduced Fe and $\mathrm{Mn}$ in UB pore water (discussed above), much of this SOC may have been due to the reoxidation of these reduced species, and not due to microbial aerobic respiration directly.

The above calculations assume that the $\mathrm{SR}_{12}$ rates were measured deep enough to account for the majority of benthic SR. This was probably most valid at $M B$, where both $\mathrm{SO}_{4}^{2-}$ and $\mathrm{SR}$ rates decrease rapidly within the top $12 \mathrm{~cm}$ (Figs. 3 \& 5). However, at UB and LB the measured $\mathrm{SR}_{12}$ rates may not have incorporated the complete SR zone, as averaged profiles were nearly vertical down to at least this depth (Fig. 5). Thus, the percentage of annual primary production consumed via SR may be underestimated at these sites, particularly when bioturbation may actively mix freshly deposited organic material to depth in the sediment.

Estimates of the fraction of organic carbon reaching the benthos in each Bay region were also given in Kemp et al. (1997) (from Kerhin et al. 1983) as 0.72 (UB), $0.47(\mathrm{MB}$ ) and 0.47 (LB). From these, we calculate that 25 to $35 \%$ (UB), $68 \%(\mathrm{MB})$, and $45 \%$ (LB) of the phytoplankton detritus deposited to the benthos is mineralized via SR. Our MB estimate compares favorably with the results of Roden et al. (1995), who concluded that 70 to $85 \%$ of newly deposited organic C was mineralized via SR in the mesohaline region, and with the $\sim 66 \%$ value reported for Aarhus Bay coastal marine sediments (Moeslund et al. 1994). The estimates of annual $\mathrm{C}$ flow through SR for the oligohaline and polyhaline Chesapeake Bay, presented here, are the first reported for these regions. While the current calculations are crude, and subject to the uncertainty inherent in the estimates of deposition, gross primary production, and reduced-S reoxidation, they suggest that the extent of $C$ flow through $\mathrm{SR}$ may vary greatly among distinct regions of an estuary, due to differences in macrobiological and biogeochemical conditions.

\section{CONCLUSION}

As we seek to develop a more detailed understanding of the factors which mediate SR at the ecosystem level, we need to recognize the often complex interaction of physical, biological, and chemical variables which impact these processes. Seemingly simple relationships between rates of microbial metabolism and temperature, or the availability of suitable electron donors and acceptors, are often confounded by these interactions, and are not necessarily constant over large spatial scales. The results from the current investigation at site $\mathrm{MB}$ confirm earlier assessments of annual SR rates, reduced-S burial and annually integrated $C$ flow through SR in the mesohaline Chesapeake Bay, and extend these measurements to the oligohaline and polyhaline regions. The transition in organic quality from primarily refractory terrestrial material in the oligohaline to more labile phytoplankton further down-bay influenced the spatial distribution of SR rates more strongly than did the absolute quantity of organic material deposited. One implication of this is that practices which limit erosion in the 
upper watershed, thus leading to less turbid conditions and enhanced primary production in the oligohaline, may lead to increased rates of benthic SR in this region. The relative influences of organic quality and quantity may similarly impact spatial trends of SR in other estuarine systems which receive significant terrestrial organic input. The calculation of $C_{l}$ (or $E_{a}$ ) values from seasonal field data, using in situ incubation temperatures, does not reflect a measure of microbial enzyme kinetics explicitly, as it includes other temperature-dependent factors (e.g. microbial community composition, macrofauna activity, or redox conditions) which also affect microbial rates. The apparent influence of temperature on SR rates, measured in this way, will likely vary spatially, both among different regions of an ecosystem and with sediment depth. The potential for enhanced reduced-S burial and reoxidation in estuarine regions with low rates of $S R$ and high concentrations of reactive $\mathrm{Fe}$ and/or $\mathrm{Mn}$ is an area of biogeochemical research which should be pursued further. While the qualitative and quantitative analyses presented here are important for furthering our understanding of the role of SR in Chesapeake Bay specifically, they also provide a framework by which the spatial variations of this important ecological process may be assessed and compared in other estuarine systems.

Acknowledgements. The authors thank Walter Boynton, Jeff Cornwell, Jon Tuttle, George Helz, Jim Love, Larry Miller, and 3 anonymous reviewers for reviewing various versions of this manuscript, and gratefully acknowledge Kim Warner, Jay Burns, Genevieve Aldridge, Cindy Shoemaker, Ethel Smith, Janet Barnes, David Jasinski, Veronica Miller, Mike Wolf, Joanne Nelson, Sara Jenkins, Tom Haas, and Mary Thomas for field and laboratory assistance. We thank Walter Boynton and Jeff Cornwell for the use of their unpublished data, and the captains and crews of the RV 'Cape Henelopen' and the RV 'Ridgley Warfield'. A special thanks to Eric Roden for extended discussion regarding this work. This research was supported by National Science Foundation grants BSR8814272 and DEB-8814272 (both awarded in part to D.G.C.). We also acknowledge the Chesapeake Biological Laboratory Graduate Research Assistantship (1990-1992) and a State of Maryland Senatorial Scholarship (1989-1993) awarded to M.C.M. This paper represents UMCES CBL contribution $\# 3071$.

\section{LITERATURE CITED}

Abdollahi H, Nedwell DB (1979) Seasonal temperature as a factor influencing bacterial sulfate reduction in a salt marsh. Microb Ecol 5:73-79

Aller RC, Yingst JY (1985) Effects of the marine deposit feeders Heteromastus filiformis (Polychaeta), Macoma balthica (Bivalvia), and Tellina texana (Bivalvia) on averaged sedimentary solute transport, reaction rates, and microbial distributions. J Mar Res 43:615-645

Andersen $F \varnothing$, Helder W (1987) Comparison of oxygen microgradients, oxygen flux rates and electron transport system activity in coastal marine sediments. Mar Ecol Prog Ser 37 : $259-264$

Berner RA (1978) Sulfate reduction and the rate of deposition of marine sediments. Earth Planet Sci Lett 37:492-498

Berner RA, Westrich JT (1985) Bioturbation and the early diagenesis of carbon and sulfur. Am J Sci 285:193-206

Biggs RB, Flemer DA (1972) The flux of particulate carbon in an estuary. Mar Biol 12:11-17

Blair NE, Levin LA, DeMaster DJ, Plaia G (1996) The shortterm fate of fresh algal carbon in continental slope sediments. Limnol Oceanogr 41:1208-1219

Boudreau BP, Westrich JT (1984) The dependence of bacterial sulfate reduction on sulfate concentration in marine sediments. Geochim Cosmochim Acta 48:2503-2516

Boynton WR, Kemp WM, Barnes JM, Cowan JJW, Stammerjohn SE, Matteson LL, Rohland FM, Marvin M, Garber JH (1991) Long-term characteristics and trends of benthic oxygen and nutrient fluxes in the Maryland portion of Chesapeake Bay. In: Mihursky JA, Chaney A (eds) New perspectives in the Chesapeake system: a research and management partnership. Chesapeake Research Consortium, Solomons, MD, p 339-354

Brady JE, Humiston GE (1982) General chemistry principles and structures. John Wiley \& Sons, New York

Burdige DJ (1993) The biogeochemistry of manganese and iron reduction in marine sediments. Earth Sci Rev 35: 219284

Bussmann I, Reichardt W (1991) Sulfate-reducing bacteria in temporarily oxic sediments with bivalves. Mar Ecol Prog Ser 78:97-102

Canfield DE (1989) Sulfate reduction and oxic respiration in marine sediments: implications for organic carbon preservation in euxinic environments. Deep Sea Res 36:121-138

Capone DG, Kiene RP (1988) Comparison of microbial dynamics in marine and freshwater sediments: contrasts in anaerobic carbon catabolism. Limnol Oceanogr 33: $725-749$

Chanton JP, Martens CS, Goldhaber MB (1987) Biogeochemical cycling in an organic-rich coastal marine basin. 7. Sulfur mass balance, oxygen uptake and sulfide retention. Geochim Cosmochim Acta 51:1187-1199

Cifuentes LA, Sharp JH, Fogel ML (1988) Stable carbon and nitrogen isotope biogeochemistry in the Delaware estuary. Limnol Oceanogr 33:1102-111.5

Cline JD (1969) Spectrophotometric determination of hydrogen sulfide in natural waters. Limnol Oceanogr 14: $454-458$

Cornwell JC, Conley DJ, Owens M, Stevenson JC (1996) A. sediment chronology of the eutrophication of Chesapeake Bay. Estuaries 19:488-499

Cornwell JC, Sampou PA (1995) Environmental controls on iron sulfide mineral formation in a coastal plain estuary. In: Vairavamurthy MA. Schoonen MAA (eds) Geochemical transformations of sedimentary sulfur. ACS Symposium Series, American Chemical Society, Washington, DC, p 224-242

Cowen JLW, Boynton WR (1996) Sediment-water oxygen and nutrient exchanges along the longitudinal axis of Chesapeake Bay: seasonal patterns, controlling factors and ecological significance. Estuaries 19:562-580

Crill PM, Martens CS (1987) Biogeochemical cycling in an organic-rich coastal marine basin. 6. Temporal and spatial variations in sulfate reductions rates. Geochim Cosmochim Acta 51:1175-1186

Fallon RD (1987) Sedimentary sulfides in the nearshore Georgia Bight. Estuar Coast Shelf Sci 25:607-619

Finster K. Liesack W. Thamdrup B (1998) Elemental sulfur 
and thiosulfate disproportionation by Desulfocapsa sulfoexigens sp. nov., a new anaerobic bacterium isolated from marine surface sediment. Appl Environ Microbiol 64: $119-125$

Forster S, Graf G, Kitlar J, Powilleit M (1995) Effects of bioturbation in oxic and hypoxic conditions: a microcosm experiment with a North Sea sediment community. Mar Ecol Prog Ser 116:153-161

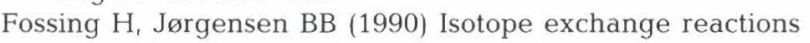
with radiolabeled sulfur compounds in anoxic seawater. Biogeochemistry 9:223-245

Harding LW Jr, Meeson BW, Fisher TR Jr (1986) Phytoplankton production in two east coast estuaries: photosynthesislight functions and patterns of carbon assimilation in Chesapeake and Delaware Bays. Estuar Coast Shelf Sci 23:773-803

Hedges JI, Clark WA, Cowie GL (1988) Organic matter sources to the water column and surficial sediments of a marine bay. Limnol Oceanogr 33:1116-1136

Hedges JI, Clark WA, Quay PD, Richey JE, Devol AH, Santos UM (1986) Composition and fluxes of particulate organic material in the Amazon River. Limnol Oceanogr 31: $717-738$

Hennessee EL, Blakeslee PJ, Hill JM (1986) The distributions of organic carbon and sulfur in surficial sediments of the Maryland portion of Chesapeake Bay. J Sediment Petrol $56: 674-683$

Hill JM, Halka J (1988) Nutrient regeneration rates in Chesapeake Bay bottom water sediments based on bulk properties. In: Lynch MP, Krome EC (eds) Understanding the estuary: advances in Chesapeake Bay research. Proceedings of a conference, 29-31 March 1988, Baltimore, MD. Chesapeake Research Consortium, Publ No. 129, p 184-200

Hines ME, Jones GE (1985) Microbial biogeochemistry and bioturbation in the sediments of Great Bay, New Hampshire. Estuar Coast Shelf Sci 20:729-742

Hines ME, Orem WH, Lyons WB, Jones GE (1982) Microbial activity and bioturbation-induced oscillations in pore water chemistry of estuarine sediments in spring. Nature 299:433-435

Hobbs CHI (1983) Organic carbon and sulfur in the sediments of the Virginia Chesapeake Bay. J Sediment Petrol 53: $383-393$

Holland AF (1985) Long-term variation of macrobenthos in a mesohaline region of Chesapeake Bay. Estuaries 8:93-113

Holland AF, Mountford NK, Mihursky JA (1977) Temporal variation in upper bay mesohaline benthic communities. Chesapeake Sci 16:370-378

Howarth RW (1979) Pyrite: its rapid formation in a salt marsh and its importance in ecosystem metabolism. Science 203: $49-50$

Howarth RW, Jørgensen BB (1984) Formation of ${ }^{35}$ S-labelled elemental sulfur and pyrite in coastal marine sediments (Limfjorden and Kysing Fjord, Denmark) during shortterm ${ }^{35} \mathrm{SO}_{4}{ }^{2-}$ reduction measurements. Geochim Cosmochim Acta 48:1807-1818

Jørgensen BB (1977) The sulfur cycle of a coastal marine sediment (Limfjorden, Denmark). Limnol Oceanogr 22: $814-832$

Jørgensen BB (1978) A comparison of methods for the quantification of bacterial sulfate reduction in coastal marine sediments. 1. Measurement with radiotracer techniques. Geomicrobiol J 1:11-27

Jørgensen BB (1990) The sulfur cycle of freshwater sediments: role of thiosulfate. Limnol Oceanogr 35:1329-1342

Jørgensen BB, Bak F (1991) Pathways and microbiology of thiosulfate transformations and sulfate reduction in a marine sediment (Kattegat, Denmark). Appl Environ Microbiol 57:847-856

Kaplan IR, Emery KO, Rittenberg SC (1963) The distribution and isotopic abundance of sulfur in recent marine sediments of southern California. Geochim Cosmochim Acta $27: 297-331$

Kemp WM, Smith EM, Marvin-DiPasquale $M$, Boynton WR (1997) Organic carbon balance and net ecosystem metabolism in Chesapeake Bay. Mar Ecol Prog Ser 150 229-248

Kerhin R, Halka J, Hennessee E, Blakeslee P, Wells D, Zoltan N, Cuthbertson R (1983) Physical characteristics and sediment budget for bottom sediments in the Maryland portion of Chesapeake Bay. US EPA, Washington, DC

King GM (1988) Patterns of sulfate reduction and the sultur cycle in a South Carolina salt marsh. Limnol Oceanogr 33 376-390

Kristensen E, Blackburn TH (1987) The fate of organic carbon and nitrogen in experimental marine sediment systems: influence of bioturbation and anoxia. J Mar Res 45 231-257

Lovley D, Klug MJ (1983) Sulfate reducers can outcompete methanogens at freshwater sulfate concentrations. Appl Environ Microbiol 45:187-192

Malone TC, Crocker LH, Pike SE, Wendler BW (1988) Influence of river flow on the dynamics of phytoplankton production in a partially stratified estuary. Mar Ecol Prog Ser 48:235-249

Matson EA, Brinson MM (1990) Stable carbon isotopes and the C:N ratio in the estuaries of the Pamlico and Neuse Rivers, North Carolina. Limnol Oceanogr 35:1290-1300

Moeslund L, Thamdrup B, Jørgensen BB (1994) Sulfur and iron cycling in a coastal sediment: radiotracer studies and seasonal dynamics. Biogeochemistry 27:129-152

Morse JW, Cornwell JC (1987) Analysis and distribution of sulfide minerals in recent marine sediment. Mar Chem 22: $55-69$

Morse JW, Wang Q (1997) Pyrite formation under conditions approximating those in anoxic sediments: II. Influence of precursor iron minerals and organic matter. Mar Chem 57 187-193

Nedwell DB, Abram JW (1979) Relative influence of temperature and electron donor and electron acceptor concentrations on bacterial sulfate reduction in saltmarsh sediment. Mircrob Ecol 5:67-72

Oremland RS, Polcin S (1982) Methanogenesis and sulfate reduction: competitive and noncompetitive substrates in estuarine sediments. Appl Environ Microbiol 44: $1270-1276$

Owens M, Cornwell JC (1995) Sedimentary evidence for decreased heavy-metal inputs to the Chesapeake Bay. Ambio 24:24-27

Peterson ML, Hernes PJ, Thoreson DS, Hedges JI, Lee C, Wakeham SG (1993) Field evaluation of a valved sediment trap. Limnol Oceanogr 38:1741-1761

Quay PD, Wilbur DO, Richey JE, Hedges JI, Devol AH, Victoria $\mathrm{R}$ (1992) Carbon cycling in the Amazon River: implications from the ${ }^{13} \mathrm{C}$ composition of particles and solutes. Limnol Oceanogr 37:857-870

Revsbech NP, Sørensen J, Blackburn TH, Lomholt JP (1980) Distribution of oxygen in marine sediments measured with microelectrodes. Limnol Oceanogr 25:403-411

Rice DL (1986) Early diagenesis in bioadvective sediments: relationships between the diagenesis of beryllium-7, sediment reworking rates, and the abundance of conveyorbelt deposit-feeders. J Mar Res 44:149-184

Roden EE, Tuttle JH (1992) Sulfide release from estuarine 
sediments underlying anoxic bottom water. Limnol Oceanogr 37:725-738

Roden EE, Tuttle JH (1993a) Inorganic sulfur cycling in mid and lower Chesapeake Bay sediments. Mar Ecol Prog Ser 93:101-118

Roden EE, Tuttle JH (1993b) Inorganic sulfur turnover in oligohaline estuarine sediments. Biogeochemistry 22: 81-105

Roden EE, Tuttle JH, Boynton WR, Kemp WM (1995) Carbon cycling in mesohaline Chesapeake Bay sediments 1: POC deposition rates and mineralization pathways. J Mar Res 53:799-819

Schubel JR, Biggs RB (1968) Distribution of seston in upper Chesapeake Bay. Chesapeake Sci 10:18-23

Skyring GW (1987) Sulfate reduction in coastal ecosystems. Geomicrobiol J 5:295-374

Smith EM, Kemp WM (1995) Seasonal and regional variations in plankton community production and respiration for Chesapeake Bay. Mar Ecol Prog Ser 116:217-231

Sørensen J, Jørgensen BB, Revsbech NP (1979) A comparison of oxygen, nitrate and sulfate respiration in coastal marine sediments. Microb Ecol 5:105-115

Strickland JDH, Parsons TR (1972) A practical handbook of seawater analysis. Fisheries Research Board of Canada, Ottawa

Editorial responsibility: Jed Fuhrman (Contributing Editor), Los Angeles, California, USA
Swider KT, Mackin JE (1989) Transformations of sulfur compounds in marsh-flat sediments. Geochim Cosmochim Acta 53:2311-2323

Thamdrup B, Finster K, Hansen JW, Bak F (1993) Bacterial disproportionation of elemental sulfur coupled to chemical reduction of iron or manganese. Appl Environ Microbiol 59:101-108

Westrich JT, Berner RA (1984) The role of sedimentary organic matter in bacterial sulfate reduction: the G model tested. Limnol Oceanogr 29:236-249

Westrich JT, Berner RA (1988) The effect of temperature on rates of sulfate reduction in marine sediments. Geomicrobiol J 6:99-117

Wilkin RT, Barnes HL (1996) Pyrite formation by reactions of iron monosulfides with dissolved inorganic and organic sulfur species. Geochim Cosmochim Acta 60:4167-4179

Wollast R (1983) Interactions in estuarine and coastal waters. In: Bolin B, Cook RB (eds) The major biogeochemical cycles and their interactions. John Wiley \& Sons, New York, p 385-407

Zhabina N, Volkov I (1978) A method of determination of various sulfur compounds in sea sediment and rocks. In: Krumbein WE (ed) Environmental biogeochemistry and geomicrobiology, Vol 3. Ann Arbor Sci Publ, Ann Arbor, p $735-746$

Submitted: August 7, 1997; Accepted: May 4, 1998 Proofs received from author(s): June 22, 1998 